\title{
Market Discipline and Deposit Insurance Reform in Japan*
}

\begin{abstract}
This paper examines the relationship between market discipline and the deposit insurance system in Japan using unique data set on bank-level weekly deposit rates in Japan. I find that when the government provided an unlimited coverage for all bank deposits, the risk profile of banks had no effect on either interest rates of deposits or the quantity of deposits. That is, depositors failed to monitor and punish risky banks. On the other hand, when the government imposed an insurance limit on time deposits, 10 million yen (approximately $\$ 100,000$ ) per depositor per bank, risky banks started offering higher interest rates on time deposits and attracting less time deposits than financially strong banks. In addition, as expected, the interest rates differential between partially insured time deposits and fully insured ordinary deposits increased for financially weak banks. These two pieces of evidence indicate the emergence of market discipline. However, after the reform, the implicit guarantee provided by the government became a more important determinant of interest rates and deposit growth, thereby partially offsetting the positive effects of deposit insurance reform on market discipline. Because of this implicit guarantee, overall effects of deposit insurance reform on market discipline are likely to be small.
\end{abstract}

Masami Imai

Wesleyan University

PAC 123

238 Church Street

Middletown, CT 06459-0007

860-685-2155

860-685-2301 (fax)

mimai@wesleyan.edu

\footnotetext{
* This research is funded by Luce Foundation and research grants from Wesleyan University. The author is grateful to Mr. Yaoita and The Japan Financial News Co., Ltd for providing the unique data on bank-level weekly interest rates on deposits, and to seminar participants at Wesleyan University (2004), Pacific Rim (2005) Conference of Western Economic Association International (2005), Bank of Japan (2005), and Japan Economic Seminar (2005) for helpful comments, and to Eli Lee, Rika Tsuchiya, and Asuka Konishi for excellent research assistance. The author is responsible for all errors and omissions.
} 
The real pre-safety-net discipline was from the market, and we need to adopt policies that promote private counterparty supervision as the first line of defense for a safe and sound banking system. Uninsured counterparties must price higher or simply not deal with banking organizations that take on excessive risk.

- Alan Greenspan, remarks at the 37th Annual Conference on Bank Structure and Competition of the Federal Reserve Bank of Chicago, Chicago, Illinois, May 10, 2001

\section{Introduction}

Deposit insurance is one of the most controversial issues in economics. In theory, deposit insurance can have either stabilizing or destabilizing effects on the banking system. On the positive side, it can reduce the likelihood of liquidity crises and bank runs because it provides assurance to depositors that their assets are safe and secure. ${ }^{1}$ On the negative side, deposit insurance can distort incentives of both banks and depositors. In particular, insured depositors lose the incentive to select and monitor the banks into which they put their deposits because their deposits are safe no matter how risky the bank is. Consequently, unmonitored banks have ample opportunity and the incentives to increase leverage and take excessive risk, which in turn destabilizes the banking sector in the long run. ${ }^{2}$

Many researchers put these two opposing views to empirical tests in which they examine the relationship between deposit insurance structures and banking sector stability. ${ }^{3}$ These studies present two important findings. First, the adoption of deposit

\footnotetext{
${ }^{1}$ Diamond and Dybvig (1983) show that even a healthy bank can be susceptible to bank runs, and that deposit insurance offers a superior contract to any that banks can privately offer in order to avoid bank runs. ${ }^{2}$ Using the standard option-pricing model, Merton (1977) shows that the value of bank equity is maximized by increasing leverage and asset risk. Furlong and Keeley (1989) later show that incentives to increase asset risk decline as its capital increases, illustrating the importance of capital adequacy regulation.

${ }^{3}$ These empirical studies can be divided into two types. One, several of them make use of variation in deposit insurance scheme across different states and/or banks in the United States before 1934 (e.g. Calomiris (1990), Gunther, Hooks, and Robinson (2000) and Hooks and Robinson (2002), Grossman (1992), Alston, Grove and Wheelock, (1994), Wheelock and Kumbhakar (1994), Wheelock and Wilson
} 
insurance increases the likelihood of banking instability. Moreover, more recent study by Demirguc-Kunt and Detragiache (2002) presents strong evidence that badly designed deposit insurance system magnifies these destabilizing effects. In particular, coverage limits play an extremely important role in keeping the probability of banking crisis low. The theoretical explanation for the importance of coverage limit is straightforward. With a sufficiently low coverage limit, regulators can ensure that some depositors, especially sophisticated large uninsured depositors, will have an incentive to monitor and punish risky banks by charging higher risk premium and withdrawing deposits.

Many financial economists deem this process of market discipline to be a critical component of financial supervision. ${ }^{4}$ However, only three papers specifically investigate the effects of the design of deposit insurance on market discipline. ${ }^{5}$ First, Mondschean and Opiela (1999) find that the sensitivity of interest rates on time deposits to the risk profile of banks declined after the explicit deposit guarantee took effect in Poland. Second, Martinez Peria and Schmukler (2001) compiled much disaggregated bank-level data on both insured and uninsured deposits in Chile, Mexico, and Argentina. Using this data, they investigate the sensitivity of deposit rates and deposit quantity to the risk profile of banks in each of these three countries before and after the adoption of deposit insurance. Surprisingly, they do not find that deposit insurance diminishes the degree of market discipline in these countries. In addition, small deposits that are explicitly covered by deposit insurance do indeed respond to variation in risk in the same manner as

(1995), and Wheelock and Kumbhakar (1995)). Two, more recent studies utilize the variation in deposit insurance design across countries to predict banking crisis (e.g. Demirguc-Kunt and Detragiache (2002), Eichengreen and Arteta (2002), and Hoggarth, Jackson, and Nier (2004)).

${ }^{4}$ See Calomiris (1999) and Evanoff and Wall (2001) among others.

${ }^{5}$ It should be noted that there is a large literature that examine and find the presence of market discipline in a particular country, mostly the United States. See Flannery (1998) for an excellent literature review. However, a very few of them actually explore the relationship between deposit insurance structure and market discipline. 
uninsured deposits. Martinez Peria and Schmukler (2002) explain that deposit insurance was not entirely credible in these countries, which in turn makes even insured deposits sensitive to bank risks. Finally, Demirguc-Kunt and Huizinga (2004) examine how the sensitivity of deposit rates and deposit quantity to the risk profile of banks varies across countries, depending on the structure of deposit insurance. Their finding is consistent with economic theory in that: (1) banks pay lower rates on deposits in countries in which the government offers generous deposit insurance coverage, and (2) this benefit is pronounced especially among financially weak banks.

This paper attempts to bring more empirical evidence to this important issue of market discipline and deposit insurance. To do so, it makes use of dramatic changes in deposit insurance coverage during 2002 in Japan as a natural experiment in which deposit insurance coverage shifted from a blanket guarantee to a limited guarantee of 10 million yen (approximately $\$ 100,000$ ) per depositor per bank.

This paper is novel in three aspects. First, it uses posted deposits rates as opposed to the implicit interest rate, i.e., ratio of interest rate expense to total deposits, which is used by both Martinez Peria and Schmukler (2001) and Demirguc-Kunt and Huizinga (2004). This implicit rate, although widely used, is a noisy variable and it tends to reflect many other factors that are unrelated to depositors' perception of bank risk. ${ }^{6}$ The use of the posted rate will provide a more accurate indicator of the risk premium that risky banks need to offer to attract deposits. This posted rate should strongly respond to the

\footnotetext{
${ }^{6}$ It is also possible that the use of implicit rate can give biased results. Suppose that a bank had a good long-term lending opportunity in the past, its implicit rate tends to be quite high because it had probably issued a large amount of long-term deposits to finance this lending opportunity. Given that the risk profile of a bank is not unrelated to past lending behavior, fluctuations in demand for loans can generate a spurious positive relation between the observed risk profile and implicit interest costs even without the presence of market discipline.
} 
reduction in insurance coverage if our theory is correct. Second, I use weekly data on the posted deposit rates. This high frequency data allows me to more precisely isolate the effects of deposit insurance reform from other disturbances in the economy. Third, this is the first study that systematically examines the deposit rates in relation to the risk profile of banks in Japan. ${ }^{7}$

Furthermore, the examination of market discipline in the bank deposit market in Japan is of interest to policy makers as they consider deposit insurance reform to enhance market discipline. ${ }^{8}$ Policy-makers often fear, given the opacity of banks, that the removal of the blanket guarantee could potentially cause systemic crisis as uninformed depositors flee from the banking system as a whole rather than imposing discipline only on financially troubled institutions. Japanese policy makers also had the same type of fear, which led them to postpone the deposit insurance reform that was planned to occur in April 2001 instead of April 2002. ${ }^{9}$ By investigating the depositors’ reaction to the removal of the blanket guarantee in Japan, policy-makers should derive invaluable lessons as to what to expect when the financial safety net is removed.

There are three empirical findings. First, the risk premium of deposits emerged after the change in insurance coverage took place, and this effect was stronger for

\footnotetext{
${ }^{7}$ Existing study on market discipline in Japan typically investigates the effects of risk profile on the share price of banks or interbank loan rates called Japan premium. They indeed find that the risk profile of banks have statistically significant effects on the share price and interbank loan rates. For example, see Peek and Rosengren (1999), Brewer, et al (2003), Brener and Pettway (2002), Spiegel and Yamamori (2004), Genay (1999), Covrig, Low, and Melvin, Michael (2004), Ito and Harada (2000). However, there is no study that investigates the presence of market monitoring in the price of deposits, which makes this paper unique. ${ }^{8}$ Three countries in Southast Asia, Indonesia, Thailand, and Malaysia, are scheduled to remove a blanket guarantee in 2005.

${ }^{9}$ Richard Koo, chief economist at Nomura Research Institute, says that if the full deposit guarantee were lifted now, the Japanese economy would collapse in 20 minutes due to a rapid shift of funds (Daily Yomiuri, May 1999). BOJ Governor Masaru Hayami, at a Dec. 19 press conference to explain the monetary policy change, said that Japan's financial system tends to face problems in the January-March final quarter of a fiscal year 2001. He further indicated that a series of corporate bankruptcies may take place in the coming January-March period.
} 
financially weaker banks. Second, weak banks tended to attract less time deposits relative to strong banks after the reform, even though weak banks tended to offer higher interest rates than strong banks. These two pieces of evidence imply that deposit insurance reform had the intended positive effects on market discipline. Second, after the reform of the formal deposit guarantee, the informal financial safety net began to affect the depositors’ selection of banks. As a result, financially weak banks that were likely to receive external financial support in case of bank failure, continued to pay favorable interest rates and expanded their deposit base just like strong banks. While this paper confirms the notion that uninsured depositors provided some level of market monitoring in Japan after a less generous deposit insurance scheme was implemented, the overall effects of deposit insurance reform on market discipline may not be large because the implicit guarantee remained in place.

The rest of the paper is organized as follows. Section 2 presents an overview of the deposit insurance and financial safety net that prevailed in Japan during the sample period, 2001-2003. Section 3 describes the data and empirical methodology. Section 4 presents the empirical results. Section 5 concludes.

\section{Financial Safety Net in Japan (2001-2003)}

\subsection{Formal Deposit Guarantee}

The Japanese government provided a formal blanket guarantee on all bank deposits until March 31, 2002, and then limited coverage so that large time deposits in excess of 10 million yen per depositor per bank were no longer completely insured. This reform is intended to reduce the taxpayers' burden of bank insolvency and increase the 
level of private supervision of the banking system among large sophisticated depositors. Although this deposit insurance reform was publicly announced and thus widely anticipated, there was widespread uncertainty as to whether the government would actually implement this reform.

This reform was scheduled to be implemented in April 2001, but it was postponed for one year. In addition, even at the end of 2001, there was no consensus on whether the blanket coverage should end as scheduled. For instance, on December 5 2001, Finance Minister Masajuro Shiokawa said Japan should introduce limits on the government's guarantee for bank deposits in April 2002 as scheduled. However, a week later, the ruling Liberal Democratic Party's policy chief said Japan should not rush the introduction of a "payoff" limited bank deposit protection or bad loan disposal. In fact, Prime Minister Junichiro Koizumi did not publicly confirm the introduction of the "payoff" bank deposit protection limits until December 20, 2001. Table 1 summarizes the relevant events on chronological order.

\subsection{Deposit Insurance Coverage under a New Scheme}

In the Japanese banking system, two types of deposits, ordinary deposits and time deposits, dominate in terms of share of total deposits. ${ }^{10}$ As illustrated in Figure 1, these two types of deposits make up more than 85 percent of total deposits in the Japanese banking system as of August 2004. Under the new limited coverage that took effect on April 1, 2002, time deposits were insured only up to 10 million yen per depositor per bank while ordinary deposits were still completely insured.

\footnotetext{
${ }^{10}$ Ordinary deposits are interest bearing deposits with no required minimum amount. The interest rates on these deposits are typically low because of the superior liquidity relative to other types of deposits. One major difference between time deposits and ordinary deposits is that time deposits specifies maturity and the penalty fee is imposed in case of deposit withdrawal before the specified maturity.
} 
Due to the half-done nature of deposit insurance reform, it was expected that depositors would shift their funds from partially insured time deposits to completely insured ordinary deposits and that time deposits would become relatively more expensive than ordinary deposits. In fact, this is exactly what happened as shown in Figures 2 - 4. Figure 2 displays that the rapid substitution of ordinary deposits for time deposits started in January 2002, coinciding with the official announcement by Prime Minister Junichiro Koizumi that Japan will move ahead with limited deposit insurance coverage.

Furthermore, Figure 3 illustrates that large time deposits that exceed the insured amount, 10 million yen, were most negatively affected by the reform; while small and medium size time deposits remained flat during 2002, large time deposits experienced a rapid fall at the beginning of 2002. Hence, this aggregate data suggests that some depositors started holding less large time deposits that were only partially insured and more ordinary deposits that remained completely insured under the new deposit insurance system. Finally, Figure 4 shows that the difference in average interest rate between 1 month large time deposits and ordinary deposits jumped up as of April 1, 2002, indicating that depositors understood the risk associated with uninsured large time deposits and required an appropriate amount of risk premium on time deposits. ${ }^{11}$

\subsection{Implicit Guarantee}

In addition to formal deposit insurance, Japanese banks/depositors enjoyed the benefit of the government's implicit guarantee that took the form of a lender of last resort (LOLR), capital injection, nationalization, and the so called "convoy system”. Under the

\footnotetext{
${ }^{11}$ Note that the observed rapid flow of deposits from large time deposits to ordinary deposits does not necessarily constitute the evidence of market discipline, which has cross sectional implication that (1) depositors demand that risky banks pay higher interest rates and/or (2) risky banks suffer deposit withdrawals.
} 
“convoy system”, the Ministry of Finance (MOF) encouraged healthy banks to acquire failing banks by giving them sufficient financial incentive such as a permission to expand branches or explicit financial assistance using the reserve held at Deposit Insurance Corporation (DIC). ${ }^{12}$

The Convoy system was declining in its importance simply because DIC did not have adequate reserves to provide healthy banks with sufficient incentive to acquire failing banks. ${ }^{13}$ As a result, the Japanese government relied mostly on capital injection and nationalization when a failing bank was considered to effect systemic risk. For example, the government implemented a large scale capital injection twice, in 1998 and 1999, while two large insolvent banks, Long-Term Credit Bank and Nippon Credit Bank, were nationalized in 1998. Under this scheme, the government protected even subordinate debt holders from a financial loss.

Furthermore, the Revised Deposit Insurance Act of 2001 also formalized the notion of systemic risk exemption (SRE) that allowed the government to inject capital into insolvent banks or nationalize them and insure all liabilities of insolvent banks, provided that their outright failures posed systemic risk. In fact, SRE was applied twice when Resona Bank was unable to meet the capital requirement in April 2003 and when Ashikaga Bank was found insolvent in November 2003. Thus, as the handling of LongTerm Credit Bank, Nippon Credit Bank, Resona Bank and Ashikaga Bank indicates, the implicit guarantee that was supported by the anticipation of future bailout may have played important role in reducing the efficacy of market discipline in Japan even after the

\footnotetext{
${ }^{12}$ Hoshi (2002) provides an excellent case study of MOF's failure resolution policy.

${ }^{13}$ In addition, MOF was no longer able to deliver regulatory rents under deregulated environment (See Hoshi, 2002).
} 
deposit insurance reform. Thus, this paper will investigate the potential effects of an implicit guarantee on market discipline as well as that of an explicit guarantee.

\section{Empirical Methodology and Data}

\subsection{Regression Equation}

I will estimate how deposit rates were related to the observable risk profile of banks and the willingness of government to provide external financial supports before and after the introduction of coverage limits. Hence, I will estimate the following baseline equations:

$R_{i t}=\beta_{0}+\beta_{1} R_{I S K}+\beta_{2} S_{i t} P P O R T_{i t}+\beta_{3} S_{I Z E_{i t}}+\beta_{4} G R O W T H+\beta_{5} R E G I O N A L_{i t}+\varepsilon_{i t}$

where $\mathrm{R}$ is the interest rate on deposits, and RISK is a measure of risk, SUPPORT is a measure of the likelihood of external financial support (i.e. an implicit guarantee), SIZE is bank size given by the log of total assets, GROWTH is asset growth, and REGIONAL is a dummy variable associated with regional banks ${ }^{14}$ and subscript $i$ and $t$ represent bank and week, respectively. In addition, dummy variables associated with each week $t$ are added to the right hand side of this equation to capture any economy wide disturbances. This equation will be estimated for the interest rates of 1 month long time deposits, ordinary deposits, and the interest rate differential between 1 month long time deposits and ordinary deposits for three different time periods- before the reform (July-September 2001), transition period (October 2001-March 2002), and after the reform (AprilDecember 2002).

\footnotetext{
${ }^{14}$ The base group is nationwide city banks.
} 
As for the statistical property of error terms, they are likely to be heteroskedastic across panels since demand and supply conditions may be more volatile for some banks than others. In addition, since these conditions are likely to be serially correlated within banks (e.g. favorable demand condition tends to be followed by another week of favorable demand condition), error terms are serially correlated within banks. Hence, generalized least square (GLS) will be used in order to obtain efficient estimates and the correct standard error for statistical inference. ${ }^{15}$

By estimating this equation, I will investigate several hypotheses. First of all, blanket coverage, if credible, is expected to remove depositor incentive to monitor either RISK or SUPPORT. ${ }^{16}$ This means, the coefficients of RISK and SUPPORT will be equal to zero before the end of the blanket guarantee. Second, the introduction of partial coverage is expected to raise the intensity of monitoring by depositors, and thus RISK and SUPPORT become important variables in the determination of interest rates in the second and the third period. In addition, the effects of RISK and SUPPORT will be stronger for partially insured time deposits than completely insured ordinary deposits, which implies that the interest differential between time deposits and ordinary deposits will be larger for financially weak banks than financially healthy banks.

\subsection{Measure of Bank Risk}

I will use Moody’s Bank Financial Strength Rating (MBFS) to measure the risk profile of banks. ${ }^{17}$ In particular, during the sample period (2001-2003), MBFS of "B" is

\footnotetext{
${ }^{15}$ I used STATA command of xtgls to implement this GLS with my panel data.

${ }^{16}$ Of course, if this explicit guarantee is not credible, then depositors will select banks based on risk and likelihood of external supports, and thus RISK and SUPPORT will not be equal to zero.

${ }^{17}$ Description of MBFS is given by Appendix.
} 
the best rating that Japanese banks received. Thus, I will use this as a base category and construct dummy variables associated with all the other ratings. Hence, the coefficients of these dummy variables capture differences between banks with a particular rating and the most financially sound Japanese banks. ${ }^{18}$

For two reasons MBFS is also an attractive measure of bank risk relative to accounting measures such as risk-based capital ratio, liquidity, and nonperforming loans ratio.. First of all, since I use very high frequency data, weekly deposit rates, it is critical to use measures of bank risk that are continuously updated in response to a change in the risk profile of banks. Accounting measures of risk such as the capital adequacy ratio and the nonperforming loans ratio become obsolete to depositors since they are updated only semiannually. In other words, in order to make a fair comparison of the sensitivity of depositors to variation in the risk profile of banks between the two time periods, before and after deposit insurance reform, I must use the measure of risk that does not become obsolete over time.

Second and more importantly, accounting variables are subject to manipulation, which in turn introduces bias due to measurement error. Accounting manipulation is well-documented especially for Japanese banks. For example, Genay (2002) illustrates that as forbearance policy was implemented in the late 1990s, the accounting measures of risk started losing explanatory power for share price performance among Japanese banks. Indeed, Peek and Rosengren (2003) document that financially troubled Japanese banks tend to allocate credit to severely impaired borrowers primarily to avoid the realization of losses on their own balance sheets. Thus, the reported amount of nonperforming loans is

\footnotetext{
${ }^{18}$ During the sample period of 2001-2003, Shizuoka Bank is the only bank that received "B" while the other banks received lower ratings.
} 
a misleading indicator of asset risk, in particular for the banks in the worst financial condition. Moreover, Fukao (2002) shows that financially weak banks and insurance companies in Japan have been engaged in what is called "double-gearing," in which banks and insurance companies within the same business group purchase stock and subordinated notes from each other in order to artificially inflate their capital adequacy ratios. ${ }^{19}$

On the other hand, Moody's, unlike banks themselves, does not have the incentive to misrepresent the financial conditions of Japanese banks because Moody's has to maintain valuable reputation as a credit rating agency. In fact, a recent systematic study by Covitz and Harrison (2003) finds no evidence that Moody's and Standard \& Poor's actually assign erroneous ratings to satisfy issuers, who are free to choose among different agencies. Hence, MBFS ratings are likely to convey more accurate information about banks' financial conditions than the accounting measures of Japanese banks.

Another unique feature of MBFS ratings that is particularly valuable to this paper is that they focus on banks' economic and financial conditions without taking into account any external support from banks’ owners, government, or other financial institutions. ${ }^{20}$ On the other hand, other ratings such as Moody’s Bank Deposit Rating (MBDR) take into account the potential external support from the government. ${ }^{21}$ Although MBDR nicely summarizes the default probability of deposits, it provides a somewhat contaminated measure of the intrinsic risk of bank insolvency given that some banks receive a good MBDR simply because of a higher level of potential external

\footnotetext{
${ }^{19}$ It has been also noted that deferred tax assets were too generously counted toward capital for troubled Japanese banks.

${ }^{20}$ Sironi (2002) and Sironi (2003) show that MBFS ratings have strong explanatory power to predict the subordinated notes and debenture yield of banks in the United States and Europe.

${ }^{21}$ Description of MBDR is given by Appendix.
} 
assistance. Hence, even if one finds that interest rates are strongly related to MBDR, it does not constitute a true test of market discipline. ${ }^{22}$ Thus, MBFS ratings allow me to put market discipline to a more stringent test in which I can examine the relationship between risk premium and true economic and financial conditions of banks, instead of the simple default probability that is summarized by deposit ratings.

\subsection{Measure of External Financial Support}

To measure the extent of external financial supports in the case of bank insolvency, I construct a variable from MBFS and MBDR. As noted in the previous subsection, the critical difference between MBFS and MBDR is that, unlike the former, the latter incorporates the likelihood of external supports in order to provide accurate information about the default probability of deposits. Hence, I can extract information about the likelihood of external support by comparing MBFS with MBDR. For example, if MBDR is “Aaa” while MBFS is " $E$ ", then it must be the case that depositors can expect a large amount of external support in the case of bank insolvency, while if MBDR is C and MBFS is E, then no external support is forthcoming. The remaining question is how to extract this information and quantify it.

It would be ideal if I could obtain the information about what MBDR banks would have received without any external support, which in turn would allow me to take the difference between the predicted MBDR and the actual MBDR as a measure of external support. However, such a measure does not exist and I would have to estimate the predicted MBDR under no failure policy.

\footnotetext{
${ }^{22}$ Market discipline requires that banks face funding costs that are increasing in their own risk profile rather than the probability of bailout.
} 
The simplest way to do this is to assume that MBFS and the predicted MBDR have linear relationship with slope 1 in the absence of external support. To check this assumption, I examine the relationship between MBFS and MBDR for both US banks and Japanese banks. It turned out that this simple linear relationship described the data fairly well, especially for financially strong US banks that would have received the same good MBDR anyway without external support. Tables 2 and 3 describe this relationship. It should be also noted that MBFS and MBDR of the most financially sound Japanese bank, Shizuoka Bank, is accurately predicted in this simple prediction scheme. ${ }^{23}$

In construction of SUPPORT, I will simply take the difference between the predicted MBDR and the actual MBDR. For example, the banks with MBFS of D and MBDR of Baa2 receive 1 for SUPPORT, while the banks with MBFS of D and MBDR of A2 receive 4 for SUPPORT.

\subsection{Data Source}

I gather my data from various sources. First of all, MBFS ratings are obtained from Lexis-Nexis Academic Universe by keeping record of every single change in MBFS ratings that took place for each bank in our sample during 2001-2003. A total of 50 Japanese banks were given MBFS ratings during this period. Since not all Japanese banks are rated by Moody’s, my sample inevitably excludes other banks, about 150 banks. However, since the rated banks tend to be large, they essentially take in more than 80 percent of total bank deposits in Japan. For deposit quantity data, I rely on Nikkin Shiryo Nenpo that contains the annual outstanding level of ordinary deposits and time deposits

\footnotetext{
${ }^{23}$ There is another noteworthy observation that is closely related to the issue of prudential regulation. That is, in Japan (and the US to some extent), this simple linear relationship tends to break down as MBFS worsens. Therefore, Moody's is anticipating more external support for financially weak Japanese banks.
} 
for these banks. ${ }^{24}$ For interest rates on deposits, Japan Financial News Co. collects posted interest rates on various types of deposits.

\section{Empirical Result}

\subsection{Descriptive Statistics}

\subsubsection{Cross-Sectional Variation in Interest Rates}

If depositors intensified market monitoring after the end of the blanket guarantee, then banks must have been required to offer different interest rates according to their risk profiles. Hence, the cross sectional variability of interest rates must have increased with the introduction of partial coverage especially for time deposits. Figure 5 plots the standard deviation of both time deposits and ordinary deposits. This figure makes it clear that the cross sectional variability of interest rates of time deposits started to increase at the end of 2001, reached its peak in April 2002 and remained high. Similarly, the cross sectional variability of ordinary deposits also rose about the same time, but it quickly declined by the mid 2002 .

Another empirical implication of deposit insurance reform in Japan is that banks of different risk levels will be required to offer different relative interest rates of partially insured time deposits to fully insured ordinary deposits. Thus, the cross sectional variation of interest rate differentials between time deposits and ordinary deposits should rise in April 2002. Figure 6 plots the standard deviation of the interest premium of time deposits over ordinary deposits. Note that the cross sectional variation of the difference in interest rates between time deposit and ordinary deposit started rising rapidly in March 2002, reached it peak in April 2002, and remained permanently high.

${ }^{24}$ Unfortunately, I do not have the quantity of large time deposits that are uninsured. 


\subsubsection{Explanatory Power of Bank Risk for Cross-Sectional Variation in Interest Rates}

The emergence of market discipline also implies that the observed cross sectional variation in interest rates must be explained by the cross sectional variation in bank risk. To check this, I estimate cross sectional regression that relates interest rates to dummy variables associated with MBFS for each week. ${ }^{25}$ It is expected that MBFS' explanatory power in this regression must have risen if deposit insurance reform indeed induced depositors to become sufficiently selective so that financially weak banks were forced to offer higher interest rates for their deposits than financially strong banks.

First of all, I plot in Figure 7 the R-squares of estimated equations; it is quite remarkable that R-squares for both the time deposit equation and the ordinary deposit equation are less than 0.03 at the beginning of the sample period. That is, the Moody's evaluations of Japanese banks' financial condition were virtually unrelated to the interest rates on deposits, and MBFS ratings contained no valuable information in pricing bank deposits.

However, this would quickly change as the scheduled removal of blanket coverage approached. In particular, by the end of 2001, MBFS started showing some explanatory power for both ordinary deposit rates and time deposit rates, which is illustrated by a jump in the R-square for both the ordinary deposit equation and the time deposit equation on October 1, 2001. Furthermore, it should be also noted that the Rsquare for time the deposit equation exhibits a large jump one week before April 1, 2002, demonstrating the heightened sensitivity of depositors to the banks' risk profile on the

\footnotetext{
${ }^{25}$ Recall that the base group is MBFS of "B”, which means that the coefficient on each dummy variable is a simple difference in means between weak banks and strong banks with "B" during a particular week.
} 
eve of deposit insurance reform. In addition, notice that the R-square of time deposit equations is consistently higher than that of the ordinary deposit equation after the removal of the blanket coverage of time deposits. This result is consistent with the notion that the deposit insurance reform in Japan had the intended effects on market monitoring in the sense that depositors started pricing risk in the interest rates of partially insured time deposits.

Of course, a high R-square does not mean that MBFS ratings became statistically significant determinants of the risk premiums of deposit rates in Japan. To verify this, I test the joint significance of MBFS ratings for each equation and plot the p-value associated with each test on Figure 8. Consistent with the previous figure, the p-value started to decline on October 1, 2001. However, one cannot reject the null hypothesis that MBFS ratings have no effects on deposit rates at 5 percent significance level until year 2002.

Furthermore, the information content of MBFS ratings in determining the interest rates of time deposits and ordinary deposits started to differ after April 1, 2002. On the one hand, MBFS ratings have statistically significant effects on time deposits rates in a consistent manner after April 1, 2002. On the other hand, MBFS ratings in ordinary deposit equation quickly started becoming insignificant factors, evaluated at 5 percent confidence level. In summary, this evidence is consistent with the view that the coverage limit of deposit insurance plan does indeed have positive effects on market monitoring.

Finally, Figure 9 plots the estimated risk premium associated with different MBFS ratings. The solid line and dotted line represent the risk premium that these banks need to pay relative to banks with a "B" MBFS ratings for time deposits and ordinary 
deposits, respectively. Large dots mean that the estimated risk premiums are statistically discernible from zero at $5 \%$ significance level. There are three noteworthy results that come out this estimation.

First of all, notice that regardless of MBFS ratings, all banks were paying the same rate for both time and ordinary deposits in the early 2001 when all depositors were protected by blanket coverage. In other words, banks with an “E” MBFS rating on average offered the same rate as banks with a " $\mathrm{B}$ ” MBFS rating. This observation suggests the complete lack of market monitoring in Japan during the pre-deposit insurance reform period.

Second, financially weak banks started paying higher rates on both time deposits and ordinary deposits than banks with a "B” MBFS ratings in the end of 2001 although the estimated risk premiums of ordinary deposits are typically lower than those of time deposits. Moreover, these risk premiums for time deposits are much higher and statistically significant for banks with exceptionally low MBFS ratings such as “D”, “D-“, $\mathrm{E}+$, and “E”.

Third, while risk premiums of ordinary deposits started diminishing as of April 1, 2002, those of time deposits were remarkably persistent. As a result, there is a difference in the interest rates between time deposits and ordinary deposits for financially weak banks. These observations are consistent with the view that financially weak banks were forced to pay higher rates on uninsured time deposits relative to financially strong banks in Japan only after the blanket coverage of all deposits was lifted, that is, market monitoring was strengthened in the deposit market in Japan as a result of deposit insurance reform 


\subsection{Estimation Results}

Table 4 reports the estimation results of the regression model that relates interest rates to the risk profile of banks and is a measure of external support. First of all, it should be noted in Column 1, 2, and 3 that during the pre-reform period, all of the coefficients of dummy variables associated with MBFS are not statistically significant. That is, the interest rates of deposits were not related to bank risk at all, which validates the view that a blanket guarantee removes depositors’ incentive to monitor bank risk and potential external assistance. ${ }^{26}$ Second, consistent with the strengthening of market discipline, the sensitivity of the interest rates of deposits with respect to both bank risk and potential financial support rose in the expected direction in the second and the third period as noted in Columns 4, 5, 7, and 8. In other words, depositors began closely monitoring these banks, which in turn induced banks to offer interest rates according to their risk profile.

Moreover, the difference in interest rates between time deposits and ordinary deposits shows the expected pattern. First, by comparing Column 4 with Column 5 and Column 7 with Column 8, one should note that the coefficients of dummy variables associated with MBFS are consistently larger for time deposits equations than ordinary deposits equations. That is, although the interest rate sensitivities of both types of deposits to banks risk rose, time deposit rates were more sensitive to bank risk than ordinary deposit rates. Hence, weak banks were forced to pay more penalties when attracting partially insured time deposits than fully insured ordinary deposits.

\footnotetext{
${ }^{26}$ Although, unrelated with the issue of market discipline, regional banks are found to offer lower interest rates on both time deposits and ordinary deposits, which may represent some level of market power enjoyed by regional banks in terms of local deposit collection.
} 
Although these results indicate the emergence of market discipline resulting from deposit insurance reform, it is important to note that the implicit guarantee given by the government became an important determinant of interest rates. For example, as indicated in the coefficient of "External Support", after the deposit insurance reform, those banks that anticipated a higher level of implicit guarantee started enjoying lower risk premiums relative to banks with a lower level of implicit guarantee. To see the importance of the implicit guarantee, consider how much risk premium banks with MBFS of "E" are required to pay to attract time deposits. If these banks do not have any external supports, then according to Column 8 of Table 3, they will have to pay an interest rate 0.014 percent higher relative to banks with MBFS of "B”. However, as noted by Table 2, 7 out of 15 banks with "E” ratings enjoyed external support of 5. Given this high level of external support, this regression result suggests that the weakest banks end up paying the premium of $0.014-5(0.0023)=0.014-0.0115=0.0025$, which turns out to be roughly equal to the same risk premium for the two relatively strong banks that received MBFS of " $\mathrm{C}+$ " and support level of "1" (Table 2). Therefore, it is safe to say that the continuation of the implicit guarantee offset the positive effects of deposit insurance reform on market discipline.

\subsection{Deposit Quantity}

This section will check whether or not unobserved demand factors are driving my main results- that risk premiums emerged as a consequence of deposit insurance reform. For example, one can think of a scenario in which weak banks start aggressively pursuing more deposits by raising interest rates after the reform. If this "gambling for resurrection" is driving the results, then one should have observed that these weak banks' deposits 
were expanding more rapidly than strong banks'. On the other hand, if it is the supply of deposits that shifts, resulting from the deposit insurance reform that caused a hike in interest rates for weak banks, then one should observe that these banks experienced deposit outflow. In addition, one should also observe that weak banks experienced a rapid outflow of partially insured time deposits rather than ordinary deposits.

In order to check the validity of these two competing explanations, I estimate a regression equation that relates deposit growth to RISK and SUPPORT using bank-level data on deposit quantity data from 2001 to $2003 .^{27}$ The difference between this deposit growth equation and the deposit rate equation is that the former uses annual data while the latter uses weekly data due to availability. Given that RISK and SUPPORT change during a given year, I construct an index that captures the average RISK and SUPPORT during a given year for a particular bank.

First, I assign numerical values associated with MBFS as follows: "B”=0, "B-"=1, “C+"=2, “C”=3, “C-"=4, "D+"=5, “D”=6, “D-"=7, “E+"=8, and "E"=9. To derive the annualized measure of RISK for each bank, I will take a weighted average of these numbers where the weights are given by the proportion of time that banks received a particular MBFS during a given year as follows:

$R I S K=\frac{T_{B}}{365}(0)+\frac{T_{B-}}{365}(1)+\frac{T_{C+}}{365}(2)+\frac{T_{C}}{365}(3)+\frac{T_{C-}}{365}(4)+\frac{T_{D+}}{365}(5)+\frac{T_{D}}{365}(6)+\frac{T_{D-}}{365}(7)+\frac{T_{E+}}{365}(8)+\frac{T_{E}}{365}(9)$ Similarly, I take a weighted average of SUPPORT to annualize this variable as well.

Using these two variables as key explanatory variables, I estimate the following equation: $Q_{i t}=\beta_{0}+\beta_{1}$ RISK $_{i t}+\beta_{2} S_{U P P O R T}+\beta_{3} S I Z E+\beta_{4} R E G I O N A L_{i t}+\varepsilon_{i t}$

\footnotetext{
${ }^{27}$ No weekly data is available for deposit quantity.
} 
where Q measures deposit growth, and RISK and SUPPORT are the annualized measures of bank risk and external support as described above. I estimate this equation for time deposits, ordinary deposits, and total deposits for two different time periods, pre-reform (2001) and post-reform (2002).

Table 5 reports the estimation results. Columns 1, 2, and 3 show the similar pattern that emerged in Columns 1, 2, and 3 of Table 4. That is, bank risk and external support are not statistically significant determinants of deposit growth. This is consistent with the view that a blanket guarantee removes depositor incentive to monitor banks. Second, weak banks attracted less time deposits than strong banks after the removal of the blanket guarantee. This result is consistent with a leftward shift in supply schedule of time deposits rather than a rightward shift in demand schedule. Finally, the growth rates of fully insured ordinary deposits are insensitive to bank risk unlike time deposits both before and after the reform. Hence, market monitoring began functioning through the flow of partially insured time deposits, not fully insured ordinary deposits. However, although weak banks maintained the same amount of ordinary deposits, they experienced deposit outflow relative to strong banks since the outflow of time deposits was large enough, as shown in Column 6. Thus, these sets of evidence from deposit growth are largely consistent with the view that depositors started imposing costs that are positively associated with bank risk.

Nevertheless, Table 5 also shows that banks started relying more on the implicit guarantee to attract deposits. Columns 5 and 6 show that banks with a high level of external support started attracting more deposits, especially partially insured time 
deposits. Hence, the presence of an implicit guarantee partly nullifies the positive effects of deposit insurance reform on market discipline.

\section{Conclusion and Policy Implication}

This paper uses the deposit insurance reform of April 2002 in Japan as a natural experiment to test whether the introduction of coverage limits enhanced market discipline in Japan. Four important findings are uncovered. First, during early 2001 when all deposits were explicitly guaranteed, there is no evidence of market monitoring; i.e. financially weak banks were able to pay the same interest rates as financially strong banks without experiencing a rapid withdrawal of deposits. Second, at the onset of the change in deposit insurance coverage, depositors started requiring higher interest rates on time deposits that were scheduled to be only partially insured from financially weak banks. In addition, weak banks experienced an outflow of deposits, in particular time deposits. Third, not only did weak banks begin to pay higher rates on time deposits, they started paying higher interest rate premium on partially insured time deposits relative to fully insured ordinary deposits.

In sum, these results suggest that market monitoring emerged in Japan as the government removed the blanket guarantee. However, the implicit guarantee began to

play a more important role in determining how deposits were allocated among banks in Japan; i.e. some severely distressed banks continued to pay the same interest rates as healthy banks without suffering from a rapid outflow of deposits simply because depositors anticipated external supports from the government. It is safe to say that while the deposit insurance reform strengthened market discipline, the failure to remove the 
implicit guarantee partially offset the positive effects of deposit insurance reform on market discipline. 


\section{References}

Alston, Lee J; Grove, Wayne A; Wheelock, David C. "Why Do Banks Fail? Evidence from the 1920s.” Explorations in Economic History. Vol. 31 (4). p 409-31. October 1994.

Bliss, Robert R; Flannery, Mark J. "Market Discipline in the Governance of U.S. Bank Holding Companies: Monitoring vs. Influencing.” European Finance Review. Vol. 6 (3). p 361-95. 2002.

Bremer, Marc; Pettway, Richard H. "Information and the Market's Perceptions of Japanese Bank Risk: Regulation, Environment, and Disclosure.” Pacific-Basin Finance Journal. Vol. 10 (2). p 119-39. April 2002.

Brewer, Elijah, III, et al. "Does the Japanese Stock Market Price Bank-Risk? Evidence from Financial Firm Failures.” Journal of Money, Credit \& Banking. Vol. 35 (4). p 50743. August 2003.

Calomiris, Charles W. Building an Incentive-Compatible Safety Net.. Journal of Banking \& Finance. Vol. 23 (10). p 1499-1519. October 1999.

Calomiris, Charles W; Powell, Andrew. "Can Emerging Market Bank Regulators Establish Credible Discipline? The Case of Argentina, 1992-1999.” National Bureau of Economic Research, Inc, NBER Working Papers: 7715. 2000.

Calomiris, Charles W. "Is Deposit Insurance Necessary? A Historical Perspective.” The Journal of Economic History. Vol. 50 (2). p 283-95. June 1990.

Covitz, Daniel M; Harrison, Paul. "Testing conflicts of interest at bond rating agencies with market anticipation: evidence that reputation incentives dominate.” Board of Governors of the Federal Reserve System (U.S.), Finance and Economics Discussion Series: 2003-68. 2003.

Covrig, Vicentiu; Low, Buen Sin; Melvin, Michael. “A Yen Is Not a Yen: TIBOR/LIBOR and the Determinants of the Japan Premium.” Journal of Financial \& Quantitative Analysis. Vol. 39 (1). p 193-208. March 2004.

Diamond, Douglas W; Dybvig, Philip H. "Bank Runs, Deposit Insurance, and Liquidity.” Journal of Political Economy. Vol. 91 (3). p 401-19. June 1983.

Demirguc-Kunt, Asli; Detragiache, Enrica. "Does Deposit Insurance Increase Banking System Stability? An Empirical Investigation.” Journal of Monetary Economics. Vol. 49 (7). p 1373-1406. October 2002.

Demirguc-Kunt, Asli; Kane, Edward J. "Deposit Insurance around the Globe: Where Does It Work?” Journal of Economic Perspectives. Vol. 16 (2). p 175-95. Spring 2002. 
Demirguc-Kunt, Asli; Huizinga, Harry. "Market Discipline and Deposit Insurance.” Journal of Monetary Economics. Vol. 51 (2). p 375-99. March 2004.

Eichengreen, Barry; Arteta, Carlos. "Banking Crises in Emerging Markets: Presumptions and Evidence.” Financial policies in emerging markets. Blejer, Mario Skreb, Marko, eds., Cambridge and London: MIT Press. p 47-94. 2002.

Evanoff, Douglas D; Wall, Larry D. Reforming Bank Capital Regulation: Using Subordinated Debt to Enhance Market and Supervisory Discipline. Contemporary Economic Policy. Vol. 19 (4). p 444-53. October 2001.

Flannery, Mark J. "Using Market Information in Prudential Bank Supervision: A Review of the U.S. Empirical Evidence.” Journal of Money, Credit \& Banking. Vol. 30 (3). p 273-305. Part 1 Aug. 1998.

Fukao, Mitsuhiro. "Financial Sector Profitability and Double-Gearing.” National Bureau of Economic Research, Inc, NBER Working Papers: 9368. 2002.

Furlong, Frederick T; Keeley, Michael C. "Capital Regulation and Bank Risk-Taking: A Note.” Journal of Banking \& Finance. Vol. 13 (6). p 883-91. December 1989.

Grossman, Richard S. "Deposit Insurance, Regulation, and Moral Hazard in the Thrift Industry: Evidence from the 1930's.” American Economic Review. Vol. 82 (4). p 800-821. September 1992.

Gunther, Jeffery W; Hooks, Linda M; Robinson, Kenneth J. "Adverse Selection and Competing Deposit Insurance Systems in Pre-depression Texas.” Journal of Financial Services Research. Vol. 17 (3). p 237-58. September 2000.

Genay, Hesna. “Assessing the Condition of Japanese Banks: How Informative Are Accounting Earnings?” Asymmetries in financial globalization. Batavia, Bala Lash, Nicholas A. Malliaris, Anastasios G., eds., Studies in Economic Transformation and Public Policy. Toronto: APF Press. p 141-61. 2002.

Hoggarth, Glenn; Jackson, Patricia; Nier, Erlend. "Banking Crisis and the Design of Safety Net.” Journal of Banking \& Finance (forthcoming)

Hooks, Linda M; Robinson, Kenneth J. "Deposit Insurance and Moral Hazard: Evidence from Texas Banking in the 1920s.” The Journal of Economic History. Vol. 62 (3). p 83353. September 2002.

Hoshi, Takeo. The Convoy System for Insolvent Banks: How It Originally Worked and Why It Failed in the 1990s. Japan \& the World Economy. Vol. 14 (2). p 155-80. April 2002. 
Ito, Takatoshi; Harada, Kimie. "Japan Premium and Stock Prices: Two Mirrors of Japanese Banking Crises.” National Bureau of Economic Research, Inc, NBER Working Papers: 7997. 2000.

Martinez Peria, Maria Soledad; Schmukler, Sergio L. "Do Depositors Punish Banks for Bad Behavior? Market Discipline, Deposit Insurance, and Banking Crisis.” Journal of Finance. Vol. 56 (3). p 1029-51. June 2001.

Merton, Robert C. "An Analytic Derivation of the Cost of Deposit Insurance and Loan Guarantees: An Application of Modern Option Pricing Theory.” Journal of Banking and Finance. Vol. 1 (1). pp3-11. 1977.

Mondschean, Thomas S; Opiela, Timothy P. "Bank Time Deposit Rates and Market Discipline in Poland: The Impact of State Ownership and Deposit Insurance Reform.” Journal of Financial Services Research. Vol. 15 (3). p 179-96. May 1999.

Peek, Joe; Rosengren, Eric S. "Determinants of the Japan Premium: Actions Speak Louder Than Words.” Journal of International Economics. Vol. 53 (2). p 283-305. April 2001.

Peek, Joe; Rosengren, Eric S. "Unnatural Selection: Perverse Incentives and the Misallocation of Credit in Japan.” National Bureau of Economic Research, Inc, NBER Working Papers: 9643. 2003.

Sironi, Andrea. "Testing for Market Discipline in the European Banking Industry: Evidence from Subordinated Debt Issues.” Journal of Money, Credit \& Banking. Vol. 35 (3). p 443-72. June 2003.

Sironi, Andrea. "Strengthening Banks' Market Discipline and Leveling the Playing Field: Are the Two Compatible?” Journal of Banking \& Finance. Vol. 26 (5). p 1065-91. May 2002.

Spiegel, Mark M; Yamori, Nobuyoshi. "The Evolution of Bank Resolution Policies in Japan: Evidence from Market Equity Values.” Journal of Financial Research. Vol. 27 (1). p 115-32. Spring 2004.

Wheelock, David C; Kumbhakar, Subal C. "The Slack Banker Dances:" Deposit Insurance and Risk-Taking in the Banking Collapse of the 1920s." Explorations in Economic History. Vol. 31 (3). p 357-75. July 1994.

Wheelock, David C; Kumbhakar, Subal C. "Which Banks Choose Deposit Insurance? Evidence of Adverse Selection and Moral Hazard in a Voluntary Insurance System." Journal of Money, Credit \& Banking. Vol. 27 (1). p 186-201. February 1995. 
Wheelock, David C; Wilson, Paul W. "Explaining Bank Failures: Deposit Insurance, Regulation, and Efficiency.” Review of Economics \& Statistics. Vol. 77 (4). p 689-700. November 1995. 


\section{Appendix A \\ Bank Financial Strength Ratings}

Moody’s Bank Financial Strength Ratings (BFSRs) represent Moody’s opinion of a bank’s intrinsic safety and soundness and, as such, exclude certain external credit risks and credit support elements that are addressed by Moody's Bank Deposit Ratings. In addition to commercial banks, Moody's BFSRs may also be assigned to other types of financial institutions such as multilateral development banks, government-sponsored financial institutions and national development financial institutions.

Unlike Moody’s Bank Deposit Ratings, Bank Financial Strength Ratings do not address the probability of timely payment. Instead, Bank Financial Strength Ratings are a measure of the likelihood that a bank will require assistance from third parties such as its owners, its industry group, or official institutions.

Bank Financial Strength Ratings do not take into account the probability that the bank will receive such external support, nor do they address risks arising from sovereign actions that may interfere with a bank's ability to honor its domestic or foreign currency obligations.

Factors considered in the assignment of Bank Financial Strength Ratings include bank-specific elements such as financial fundamentals, franchise value, and business and asset diversification. Although Bank Financial Strength Ratings exclude the external factors specified above, they do take into account other risk factors in the bank's operating environment, including the strength and prospective performance of the economy, as well as the structure and relative fragility of the financial system, and the quality of banking regulation and supervision.

\section{Bank Financial Strength Rating Definitions}

\section{A}

Banks rated A possess superior intrinsic financial strength. Typically, they will be institutions with highly valuable and defensible business franchises, strong financial fundamentals, and a very predictable and stable operating environment.

\section{B}

Banks rated B possess strong intrinsic financial strength. Typically, they will be institutions with valuable and defensible business franchises, good financial fundamentals, and a predictable and stable operating environment.

\section{C}

Banks rated C possess adequate intrinsic financial strength. Typically, they will be institutions with more limited but still valuable business franchises. These banks will display either acceptable financial fundamentals within a predictable and stable operating environment, or good financial fundamentals within a less predictable and stable operating environment.

\section{D}

Banks rated D display modest intrinsic financial strength, potentially requiring some outside support at times. Such institutions may be limited by one or more of the following factors: a weak business franchise; financial fundamentals that are deficient in one or more respects; or an unpredictable and unstable operating environment.

$\mathbf{E}$

Banks rated E display very modest intrinsic financial strength, with a higher likelihood of periodic outside support or an eventual need for outside assistance. Such institutions may be limited by one or more of the following factors: a weak and limited business franchise; financial fundamentals that are materially deficient in one or more respects; or a highly unpredictable or unstable operating environment.

Source: www.moodys.com 


\section{Appendix B \\ Bank Deposit Ratings}

Moody’s Bank Deposit Ratings are opinions of a bank’s ability to repay punctually its foreign and/or domestic currency deposit obligations. Foreign currency deposit ratings are subject to Moody’s country ceilings for foreign currency deposits. This may result in the assignment of a different (and typically lower) rating for the foreign currency deposits relative to the bank's rating for domestic currency obligations.

Unless otherwise indicated, Moody’s Bank Deposit Ratings apply to a bank’s foreign and domestic currency deposit obligations. A bank may also be assigned different (typically higher) domestic currency deposit ratings that are unconstrained by the respective country ceilings for foreign currency deposits.

Foreign currency deposit ratings are applicable only to banks and branches located in countries that have been assigned a country ceiling for foreign currency for bank deposits. Such obligations are rated at the lower of the bank's deposit rating or Moody's country ceiling for bank deposits for the country in which the branch is located.

Moody’s Bank Deposit Ratings are intended to incorporate those aspects of credit risk that are relevant to the prospective payment performance of the rated bank with respect to its foreign and/or domestic currency deposit obligations. Included are factors such as intrinsic financial strength, sovereign transfer risk (for foreign currency deposits), and both implicit and explicit external support elements.

Moody’s Bank Deposit Ratings do not take into account the benefit of deposit insurance schemes that make payments to depositors, but they do recognize the potential support from schemes that may provide direct assistance to banks. In addition to its Bank Deposit Ratings, Moody's also publishes Bank Financial Strength Ratings, which exclude certain of these external risk and support elements (i.e., sovereign risk and external support). Such ratings are intended to elaborate and explain Moody’s Bank Deposit Ratings, which incorporate and reflect such elements of credit risk.

\section{Long-Term Bank Deposit Ratings}

Moody’s long-term bank deposit ratings employ the same alphanumeric rating system as that for long-term issuer ratings.

\section{Aaa}

Banks rated Aaa for deposits offer exceptional credit quality and have the smallest degree of risk. While the credit quality of these banks may change, such changes as can be visualized are most unlikely to materially impair the banks' strong positions.

\section{Aa}

Banks rated Aa for deposits offer excellent credit quality, but are rated lower than Aaa banks because their susceptibility to long-term risks appears somewhat greater. The margins of protection may not be as great as with Aaarated banks, or fluctuations of protective elements may be of greater amplitude.

\section{A}

Banks rated A for deposits offer good credit quality. However, elements may be present that suggest a susceptibility to impairment over the long term.

\section{Baa}

Banks rated Baa for deposits offer adequate credit quality. However, certain protective elements may be lacking or may be characteristically unreliable over any great length of time.

\section{Ba}


Banks rated Ba for deposits offer questionable credit quality. Often the ability of these banks to meet punctually deposit obligations may be uncertain and therefore not well safeguarded in the future.

B

Banks rated B for deposits offer generally poor credit quality. Assurance of punctual payment of deposit obligations over any long period of time is small.

\section{Caa}

Banks rated Caa for deposits offer extremely poor credit quality. Such banks may be in default, or there may be present elements of danger with regard to financial capacity.

\section{$\mathrm{Ca}$}

Banks rated Ca for deposits are usually in default on their deposit obligations.

C

Banks rated C for deposits are usually in default on their deposit obligations, and potential recovery values are low.

Source: www.moodys.com 
Table 1: Chronology of Change in Deposit Insurance Scheme in Japan

\begin{tabular}{|c|c|}
\hline June 1996 & $\begin{array}{l}\text { Amendment to the Deposit Insurance Law provided a blanket } \\
\text { guarantee on all deposits until March } 2001\end{array}$ \\
\hline $\begin{array}{l}\text { January 20, } \\
1999\end{array}$ & $\begin{array}{l}\text { Finance Minister Kiichi Miyazawa said he does not support deferring } \\
\text { the April } 2001 \text { introduction of the so-called payoff system in Japan to } \\
\text { limit depositor protection in the case of failure of financial institutions. }\end{array}$ \\
\hline $\begin{array}{l}\text { January 21, } \\
1999\end{array}$ & $\begin{array}{l}\text { Kosaku Inaba, chairman of the Japan Chamber of Commerce and } \\
\text { Industry, said the government should consider putting off the abolition } \\
\text { of full protection of bank deposits scheduled for the end of March } \\
2001 \text { if the economy takes a further downturn. }\end{array}$ \\
\hline $\begin{array}{l}\text { September 29, } \\
1999\end{array}$ & $\begin{array}{l}\text { The financial-system commission of the Federation of Economic } \\
\text { Organizations (Keidanren), Japan's largest big-business group, urged } \\
\text { the government to retain the current official guarantee to fully refund } \\
\text { deposits at failed banks if removing the guarantee threatens to trigger a } \\
\text { chain reaction of bank failures. }\end{array}$ \\
\hline $\begin{array}{l}\text { December 28, } \\
1999\end{array}$ & $\begin{array}{l}\text { Japan's ruling coalition parties decided to put off for one year the } \\
\text { introduction of the planned limited deposit protection for banks and } \\
\text { other deposit-taking institutions. }\end{array}$ \\
\hline $\begin{array}{l}\text { November 2, } \\
2001\end{array}$ & $\begin{array}{l}\text { Financial Services Minister Hakuo Yanagisawa said he has no } \\
\text { intention of further delaying Japan's shift from blanket to partial } \\
\text { deposit insurance }\end{array}$ \\
\hline $\begin{array}{l}\text { November 21, } \\
2001\end{array}$ & $\begin{array}{l}\text { Bank of Japan Governor Masaru Hayami said he hopes that Japan will } \\
\text { end blanket deposit protection in April } 2002 \text { as scheduled. }\end{array}$ \\
\hline $\begin{array}{l}\text { November 28, } \\
2001\end{array}$ & $\begin{array}{l}\text { Bank of Japan Governor Masaru Hayami said he hopes that the } \\
\text { government will introduce "payoff" limited bank deposit protection as } \\
\text { planned in April } 2002 \text { to replace the current full guarantee system. }\end{array}$ \\
\hline $\begin{array}{l}\text { December 5, } \\
2001\end{array}$ & $\begin{array}{l}\text { Finance Minister Masajuro Shiokawa said Japan should introduce } \\
\text { limits on the government's guarantee for bank deposits in April } 2002 \\
\text { as scheduled under a so-called payoff scheme. }\end{array}$ \\
\hline $\begin{array}{l}\text { December 11, } \\
2001\end{array}$ & $\begin{array}{l}\text { The ruling Liberal Democratic Party's policy chief said Japan should } \\
\text { not rush the introduction of a "payoff" limited bank deposit protection } \\
\text { or bad loan disposal. }\end{array}$ \\
\hline $\begin{array}{l}\text { December 12, } \\
2001\end{array}$ & $\begin{array}{l}\text { Liberal Democratic Party Secretary-General Taku Yamasaki said } \\
\text { Japan should end its full bank deposit protection and shift to a payoff } \\
\text { limited protection next April as planned now. }\end{array}$ \\
\hline $\begin{array}{l}\text { December 20, } \\
2001\end{array}$ & $\begin{array}{l}\text { Prime Minister Junichiro Koizumi told a key Liberal Democratic Party } \\
\text { official Japan will introduce the "payoff" bank deposit protection } \\
\text { limits in April } 2002 \text { as scheduled. }\end{array}$ \\
\hline
\end{tabular}

Source: Jiji Press Ltd 
Table 2: Moody's Financial Strength Ratings and Long Term Deposit Ratings of US Banks (October 2004)

\begin{tabular}{c|cccccccccccc}
\hline & $A$ & $B+$ & $B$ & $B-$ & $C+$ & $C$ & $C-$ & $D^{+}$ & $D$ & $D-$ & $E+$ & $E$ \\
\hline$A a l$ & $\mathbf{6}$ & 0 & 0 & 3 & 0 & 0 & 0 & 0 & 0 & 0 & 0 & 0 \\
$A a 2$ & 0 & $\mathbf{1 0}$ & 1 & 4 & 1 & 0 & 0 & 0 & 0 & 0 & 0 & 0 \\
$A a 3$ & 0 & 1 & $\mathbf{1 8}$ & 5 & 1 & 4 & 0 & 1 & 0 & 0 & 0 & 0 \\
$A 1$ & 0 & 0 & 1 & $\mathbf{1 4}$ & 0 & 4 & 0 & 0 & 0 & 0 & 0 & 0 \\
$A 2$ & 0 & 0 & 0 & 0 & $\mathbf{2 1}$ & 0 & 0 & 0 & 1 & 0 & 0 & 0 \\
$A 3$ & 0 & 0 & 0 & 0 & 1 & $\mathbf{1 9}$ & 1 & 0 & 0 & 0 & 0 & 0 \\
Baal & 0 & 0 & 0 & 0 & 0 & 1 & $\mathbf{1 3}$ & 0 & 0 & 0 & 0 & 0 \\
Baa2 & 0 & 0 & 0 & 0 & 0 & 0 & 7 & $\mathbf{1}$ & 0 & 0 & 0 & 0 \\
$B a a 3$ & 0 & 0 & 0 & 0 & 0 & 0 & 0 & 1 & $\mathbf{0}$ & 0 & 0 & 0 \\
$B a l$ & 0 & 0 & 0 & 0 & 0 & 0 & 0 & 2 & 0 & $\mathbf{0}$ & 0 & 0 \\
$B a 2$ & 0 & 0 & 0 & 0 & 0 & 0 & 0 & 0 & 3 & 0 & $\mathbf{0}$ & 0 \\
$B a 3$ & 0 & 0 & 0 & 0 & 0 & 0 & 0 & 0 & 0 & 1 & 0 & $\mathbf{0}$ \\
\hline
\end{tabular}

Source: Moody’s Website (http://www.moodys.com/cust/default.asp)

Table 3: Moody's Financial Strength Ratings and Long Term Deposit Ratings of Japanese Banks (October 2004)

\begin{tabular}{c|cccccccccccc}
\hline & $A$ & $B+$ & $B$ & $B-$ & $C+$ & $C$ & $C-$ & $D+$ & $D$ & $D-$ & $E+$ & $E$ \\
\hline Aal & $\mathbf{0}$ & 0 & 0 & 0 & 0 & 0 & 0 & 0 & 0 & 0 & 0 & 0 \\
$\mathrm{Aa} 2$ & 0 & $\mathbf{0}$ & 0 & 0 & 0 & 0 & 0 & 0 & 0 & 0 & 0 & 0 \\
$\mathrm{Aa} 3$ & 0 & 0 & $\mathbf{1}$ & 0 & 0 & 0 & 0 & 0 & 0 & 0 & 0 & 0 \\
$\mathrm{~A} 1$ & 0 & 0 & 0 & $\mathbf{0}$ & 2 & 0 & 0 & 0 & 0 & 0 & 0 & 0 \\
$\mathrm{~A} 2$ & 0 & 0 & 0 & 0 & $\mathbf{0}$ & 3 & 0 & 0 & 1 & 0 & 1 & 0 \\
$\mathrm{~A} 3$ & 0 & 0 & 0 & 0 & 0 & $\mathbf{0}$ & 0 & 6 & 1 & 0 & 7 & 0 \\
$\mathrm{Ba} 1$ & 0 & 0 & 0 & 0 & 0 & 0 & $\mathbf{0}$ & 0 & 6 & 0 & 2 & 1 \\
$\mathrm{Baa} 2$ & 0 & 0 & 0 & 0 & 0 & 0 & 0 & $\mathbf{0}$ & 2 & 1 & 4 & 0 \\
$\mathrm{Ba} 3$ & 0 & 0 & 0 & 0 & 0 & 0 & 0 & 0 & $\mathbf{0}$ & 0 & 1 & 7 \\
$\mathrm{Bal}$ & 0 & 0 & 0 & 0 & 0 & 0 & 0 & 0 & 0 & $\mathbf{0}$ & 0 & 0 \\
$\mathrm{Ba} 2$ & 0 & 0 & 0 & 0 & 0 & 0 & 0 & 0 & 0 & 0 & $\mathbf{0}$ & 0 \\
$\mathrm{Ba} 3$ & 0 & 0 & 0 & 0 & 0 & 0 & 0 & 0 & 0 & 0 & 0 & $\mathbf{0}$ \\
\hline
\end{tabular}


Table 4: Relationship between Interest Rates and Bank Risk

The estimation method is Generalized Least Square (GLS) that accounts for heteroskedasticity across panels and serial correlation with panels.

\begin{tabular}{|c|c|c|c|c|c|c|c|c|c|}
\hline & \multicolumn{3}{|c|}{ July-September 2001} & \multicolumn{3}{|c|}{ October2001-March 2002} & \multicolumn{3}{|c|}{ April-December 2002} \\
\hline & $\begin{array}{l}\text { Ordinary } \\
\text { Deposits }\end{array}$ & $\begin{array}{l}\text { Time } \\
\text { Deposits }\end{array}$ & Difference & $\begin{array}{l}\text { Ordinary } \\
\text { Deposits }\end{array}$ & $\begin{array}{l}\text { Time } \\
\text { Deposits }\end{array}$ & Difference & $\begin{array}{l}\text { Ordinary } \\
\text { Deposits }\end{array}$ & $\begin{array}{l}\text { Time } \\
\text { Deposits }\end{array}$ & Difference \\
\hline $\mathrm{C}+$ & $\begin{array}{l}0.255 \\
(0.295)\end{array}$ & $\begin{array}{l}0.481 \\
(2.091)\end{array}$ & $\begin{array}{l}-0.001 \\
(0.018)\end{array}$ & $\begin{array}{l}0.626 * * \\
(0.306)\end{array}$ & $\begin{array}{l}1.032^{* *} \\
(0.410)\end{array}$ & $\begin{array}{l}0.355^{* *} \\
(0.159)\end{array}$ & $\begin{array}{l}0.336^{* * *} \\
(0.076)\end{array}$ & $\begin{array}{l}0.404 * * * \\
(0.092)\end{array}$ & $\begin{array}{l}0.151 \\
(0.126)\end{array}$ \\
\hline $\mathrm{C}$ & $\begin{array}{l}0.255 \\
(0.295)\end{array}$ & $\begin{array}{l}0.481 \\
(2.090)\end{array}$ & $\begin{array}{l}-0.001 \\
(0.018)\end{array}$ & $\begin{array}{l}0.783^{* * *} \\
(0.256)\end{array}$ & $\begin{array}{l}1.077^{* * *} \\
(0.384)\end{array}$ & $\begin{array}{l}0.361^{* *} \\
(0.155)\end{array}$ & $\begin{array}{l}0.428 * * * \\
(0.091)\end{array}$ & $\begin{array}{l}1.044^{* * *} \\
(0.125)\end{array}$ & $\begin{array}{l}0.683^{* * *} \\
(0.145)\end{array}$ \\
\hline $\mathrm{D}+$ & $\begin{array}{l}0.255 \\
(0.296)\end{array}$ & $\begin{array}{l}0.468 \\
(2.089)\end{array}$ & $\begin{array}{l}-0.002 \\
(0.019)\end{array}$ & $\begin{array}{l}0.392 * \\
(0.227)\end{array}$ & $\begin{array}{l}0.759 * * \\
(0.353)\end{array}$ & $\begin{array}{l}0.383^{* *} \\
(0.159)\end{array}$ & $\begin{array}{l}0.752^{* * *} \\
(0.118)\end{array}$ & $\begin{array}{l}1.190^{* * *} \\
(0.135)\end{array}$ & $\begin{array}{l}0.456^{* * *} \\
(0.164)\end{array}$ \\
\hline $\mathrm{D}$ & $\begin{array}{l}0.254 \\
(0.295)\end{array}$ & $\begin{array}{l}0.467 \\
(2.089)\end{array}$ & $\begin{array}{l}-0.002 \\
(0.020)\end{array}$ & $\begin{array}{l}1.024^{* * *} \\
(0.204)\end{array}$ & $\begin{array}{l}1.443^{* * *} \\
(0.327)\end{array}$ & $\begin{array}{l}0.404^{* *} \\
(0.159)\end{array}$ & $\begin{array}{l}0.842^{* * *} \\
(0.110)\end{array}$ & $\begin{array}{l}1.267 * * * \\
(0.129)\end{array}$ & $\begin{array}{l}0.556 * * * \\
(0.159)\end{array}$ \\
\hline D- & $\begin{array}{l}0.250 \\
(0.296)\end{array}$ & $\begin{array}{l}0.473 \\
(2.096)\end{array}$ & $\begin{array}{l}0.003 \\
(0.029)\end{array}$ & $\begin{array}{l}0.769 * * * \\
(0.230)\end{array}$ & $\begin{array}{l}1.018^{* * * *} \\
(0.343)\end{array}$ & $\begin{array}{l}0.473 * * * \\
(0.170)\end{array}$ & $\begin{array}{l}1.183^{* * *} \\
(0.162)\end{array}$ & $\begin{array}{l}1.533^{* * *} \\
(0.139)\end{array}$ & $\begin{array}{l}0.441^{* *} \\
(0.186)\end{array}$ \\
\hline $\mathrm{E}+$ & $\begin{array}{l}0.254 \\
(0.296)\end{array}$ & $\begin{array}{l}0.476 \\
(2.089)\end{array}$ & $\begin{array}{l}-0.003 \\
(0.024)\end{array}$ & $\begin{array}{l}0.809 * * * \\
(0.219)\end{array}$ & $\begin{array}{l}0.996 * * * \\
(0.332)\end{array}$ & $\begin{array}{l}0.448 * * * \\
(0.168)\end{array}$ & $\begin{array}{l}0.981^{* * *} \\
(0.110)\end{array}$ & $\begin{array}{l}1.196 * * * \\
(0.135)\end{array}$ & $\begin{array}{l}0.355^{* *} \\
(0.163)\end{array}$ \\
\hline $\mathrm{E}$ & $\begin{array}{l}0.259 \\
(0.296)\end{array}$ & $\begin{array}{l}0.478 \\
(2.090)\end{array}$ & $\begin{array}{l}-0.003 \\
(0.025)\end{array}$ & $\begin{array}{l}0.833^{* * *} \\
(0.220)\end{array}$ & $\begin{array}{l}0.968 * * * \\
(0.331)\end{array}$ & $\begin{array}{l}0.420^{* *} \\
(0.168)\end{array}$ & $\begin{array}{l}1.287^{* * *} \\
(0.134)\end{array}$ & $\begin{array}{l}1.410^{* * *} \\
(0.137)\end{array}$ & $\begin{array}{l}0.322^{*} \\
(0.169)\end{array}$ \\
\hline $\begin{array}{l}\text { External } \\
\text { Support }\end{array}$ & $\begin{array}{l}-0.001 \\
(0.007)\end{array}$ & $\begin{array}{l}-0.001 \\
(0.010)\end{array}$ & $\begin{array}{l}0.001 \\
(0.006)\end{array}$ & $\begin{array}{l}-0.002 \\
(0.022)\end{array}$ & $\begin{array}{l}0.007 \\
(0.019)\end{array}$ & $\begin{array}{l}-0.035^{*} \\
(0.020)\end{array}$ & $\begin{array}{l}-0.381^{* * *} \\
(0.045)\end{array}$ & $\begin{array}{l}-0.234 * * * \\
(0.025)\end{array}$ & $\begin{array}{l}0.149 * * * \\
(0.042)\end{array}$ \\
\hline Size & $\begin{array}{l}-0.001 \\
(0.004)\end{array}$ & $\begin{array}{l}-0.001 \\
(0.023)\end{array}$ & $\begin{array}{l}0.001 \\
(0.006)\end{array}$ & $\begin{array}{l}-0.032 \\
(0.028)\end{array}$ & $\begin{array}{l}-0.046^{*} \\
(0.027)\end{array}$ & $\begin{array}{l}0.045^{* *} \\
(0.019)\end{array}$ & $\begin{array}{l}-0.300^{* * *} \\
(0.036)\end{array}$ & $\begin{array}{l}-0.247^{* * *} \\
(0.032)\end{array}$ & $\begin{array}{l}0.100^{* * *} \\
(0.033)\end{array}$ \\
\hline $\begin{array}{l}\text { Asset } \\
\text { Growth }\end{array}$ & $\begin{array}{l}0.000 \\
(0.001)\end{array}$ & $\begin{array}{l}0.000 \\
(0.003)\end{array}$ & $\begin{array}{l}0.000 \\
(0.001)\end{array}$ & $\begin{array}{l}0.000 \\
(0.003)\end{array}$ & $\begin{array}{l}0.002 \\
(0.003)\end{array}$ & $\begin{array}{l}0.002 \\
(0.002)\end{array}$ & $\begin{array}{l}0.053^{* * *} \\
(0.004)\end{array}$ & $\begin{array}{l}0.026^{* * *} \\
(0.003)\end{array}$ & $\begin{array}{l}-0.025^{* * *} \\
(0.004)\end{array}$ \\
\hline $\begin{array}{l}\text { Regional } \\
\text { I }\end{array}$ & $\begin{array}{l}-0.007 \\
(0.027)\end{array}$ & $\begin{array}{l}-0.012 \\
(0.086)\end{array}$ & $\begin{array}{l}0.005 \\
(0.021)\end{array}$ & $\begin{array}{l}-0.574^{* * *} \\
(0.102)\end{array}$ & $\begin{array}{l}-0.652^{* * *} \\
(0.074)\end{array}$ & $\begin{array}{l}0.067 \\
(0.052)\end{array}$ & $\begin{array}{l}-1.704^{* * *} \\
(0.106)\end{array}$ & $\begin{array}{l}-1.266^{* * *} \\
(0.062)\end{array}$ & $\begin{array}{l}0.651^{* * *} \\
(0.099)\end{array}$ \\
\hline $\begin{array}{l}\text { Regional } \\
\text { II }\end{array}$ & $\begin{array}{l}-0.508^{* * *} \\
(0.112)\end{array}$ & $\begin{array}{l}-0.503^{* * *} \\
(0.179)\end{array}$ & $\begin{array}{l}0.005 \\
(0.025)\end{array}$ & $\begin{array}{l}-1.369 * * * \\
(0.229)\end{array}$ & $\begin{array}{l}-1.397 * * * \\
(0.130)\end{array}$ & $\begin{array}{l}0.305^{* *} \\
(0.154)\end{array}$ & $\begin{array}{l}-2.164 * * * \\
(0.135)\end{array}$ & $\begin{array}{l}-1.436 * * * \\
(0.077)\end{array}$ & $\begin{array}{l}0.840^{* * *} \\
(0.116)\end{array}$ \\
\hline Constant & $\begin{array}{l}1.761^{* * *} \\
(0.305)\end{array}$ & $\begin{array}{l}2.554 \\
(2.129)\end{array}$ & $\begin{array}{l}0.985^{* * *} \\
(0.113)\end{array}$ & $\begin{array}{l}1.719 * * * \\
(0.534)\end{array}$ & $\begin{array}{l}2.718^{* * *} \\
(0.571)\end{array}$ & $\begin{array}{l}-0.076 \\
(0.367)\end{array}$ & $\begin{array}{l}6.466^{* * *} \\
(0.581)\end{array}$ & $\begin{array}{l}6.260^{* * *} \\
(0.537)\end{array}$ & $\begin{array}{l}-1.223^{* *} \\
(0.585)\end{array}$ \\
\hline $\begin{array}{l}\text { Obs. } \\
\text { \# of } \\
\text { Banks }\end{array}$ & $\begin{array}{l}505 \\
46\end{array}$ & $\begin{array}{l}505 \\
46\end{array}$ & $\begin{array}{l}505 \\
46\end{array}$ & $\begin{array}{l}889 \\
47\end{array}$ & $\begin{array}{l}889 \\
47\end{array}$ & $\begin{array}{l}889 \\
47\end{array}$ & $\begin{array}{l}880 \\
40\end{array}$ & $\begin{array}{l}880 \\
40\end{array}$ & $\begin{array}{l}880 \\
40\end{array}$ \\
\hline
\end{tabular}

Standard errors in parentheses

* significant at 10\%; ** significant at 5\%; *** significant at $1 \%$ 
Table 5: Relationship Deposit Quantity and Bank Risk

Estimation method is ordinary least square. Standard error is adjusted for

heteroskedasticity.

\begin{tabular}{l|llllll}
\hline & \multicolumn{3}{l}{ lanket Guarantee $(2001)$} & \multicolumn{4}{l}{ Limited Guarantee (2002) } \\
\hline & Ordinary & Time & Total & Ordinary & Time & Total \\
& Deposits & Deposits & Deposits & Deposits & Deposits & Deposits \\
\hline RISK & 0.001 & -0.004 & -0.002 & 0.000 & $-0.033^{* * *}$ & $-0.012^{* *}$ \\
& $(0.006)$ & $(0.010)$ & $(0.007)$ & $(0.013)$ & $(0.009)$ & $(0.005)$ \\
External & 0.005 & 0.003 & -0.000 & 0.044 & $0.080^{* *}$ & $0.034^{*}$ \\
Support & $(0.016)$ & $(0.029)$ & $(0.020)$ & $(0.039)$ & $(0.036)$ & $(0.019)$ \\
SIZE & $0.034^{*}$ & -0.023 & 0.002 & $-0.193^{*}$ & -0.050 & -0.007 \\
& $(0.017)$ & $(0.016)$ & $(0.010)$ & $(0.102)$ & $(0.035)$ & $(0.029)$ \\
Regional I & $0.150^{* * *}$ & $-0.145^{*}$ & -0.051 & $-0.662^{* * *}$ & 0.035 & -0.017 \\
& $(0.037)$ & $(0.072)$ & $(0.049)$ & $(0.202)$ & $(0.047)$ & $(0.069)$ \\
Regional II & $0.165^{* * *}$ & -0.136 & -0.063 & $-0.591^{* * *}$ & -0.005 & -0.017 \\
& $(0.042)$ & $(0.086)$ & $(0.063)$ & $(0.207)$ & $(0.092)$ & $(0.098)$ \\
Constant & $-0.584^{*}$ & 0.496 & 0.043 & $3.858^{* *}$ & 0.679 & 0.149 \\
& $(0.297)$ & $(0.293)$ & $(0.183)$ & $(1.775)$ & $(0.544)$ & $(0.502)$ \\
Observations & 35 & 35 & 35 & 37 & 37 & 37 \\
R-squared & 0.58 & 0.38 & 0.23 & 0.75 & 0.42 & 0.21 \\
\hline
\end{tabular}

Robust standard errors in parentheses

* significant at $10 \%$; ** significant at $5 \%$; *** significant at $1 \%$ 
Figure 1: Share of Ordinary and Time Deposits in Japanese Banks as of August 2004

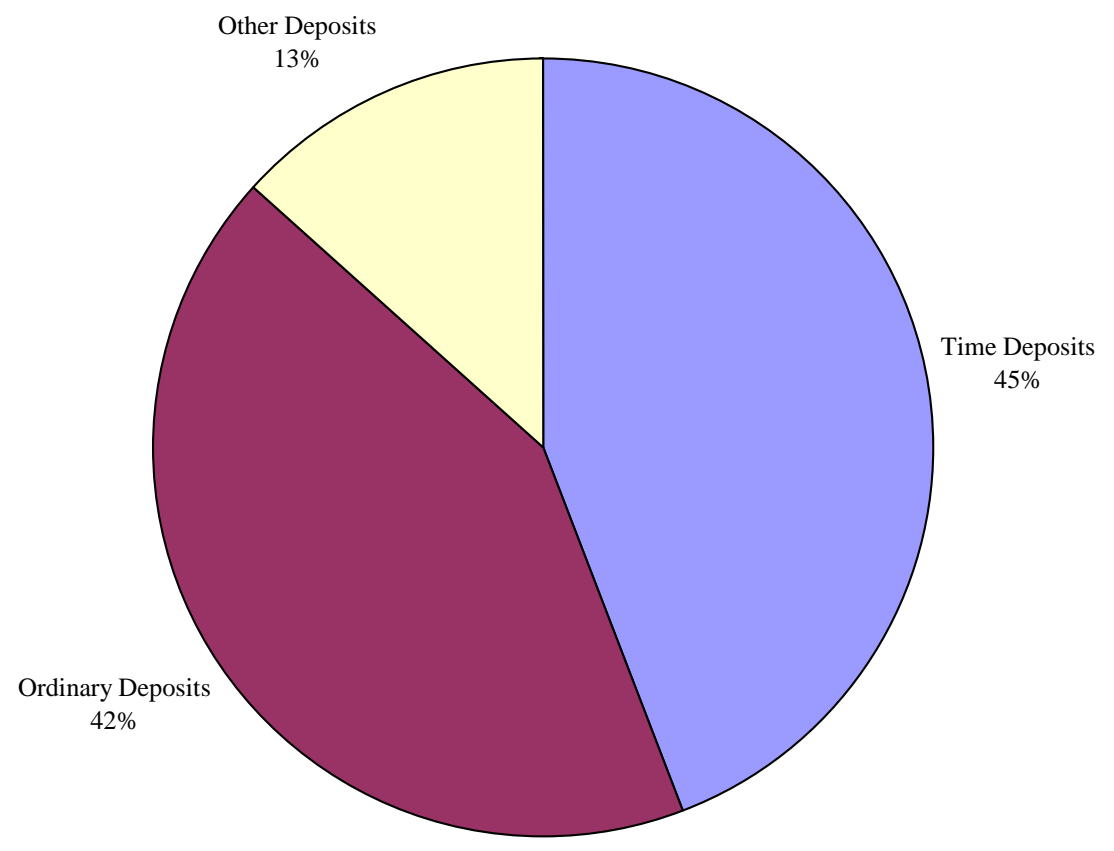

Source: Bank of Japan’s website (http://www.boj.or.jp/stat/dlong_f.htm) 
Figure 2: Amount Outstanding of Deposits

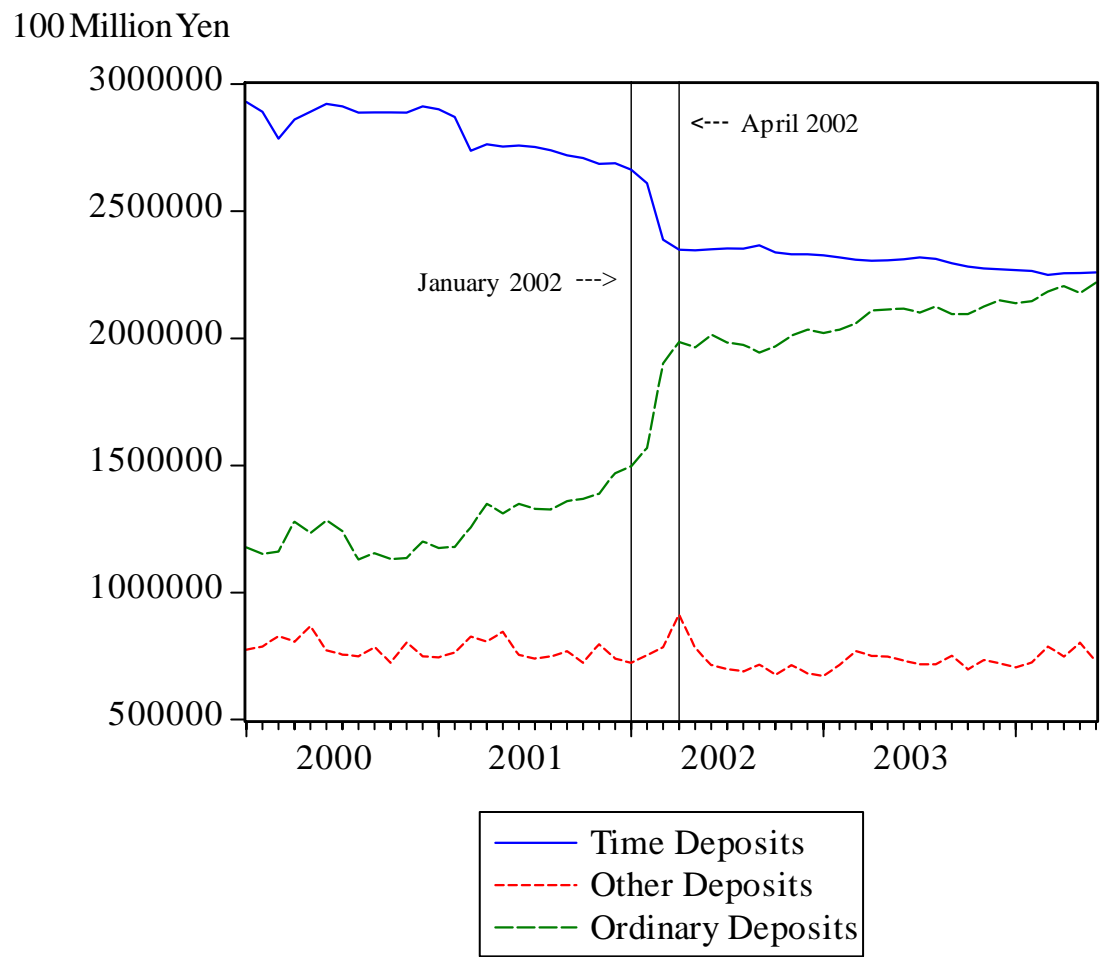

Source: Bank of Japan’s website (http://www.boj.or.jp/stat/dlong_f.htm)

Figure 3: Amount Outstanding of Time Deposits by Size

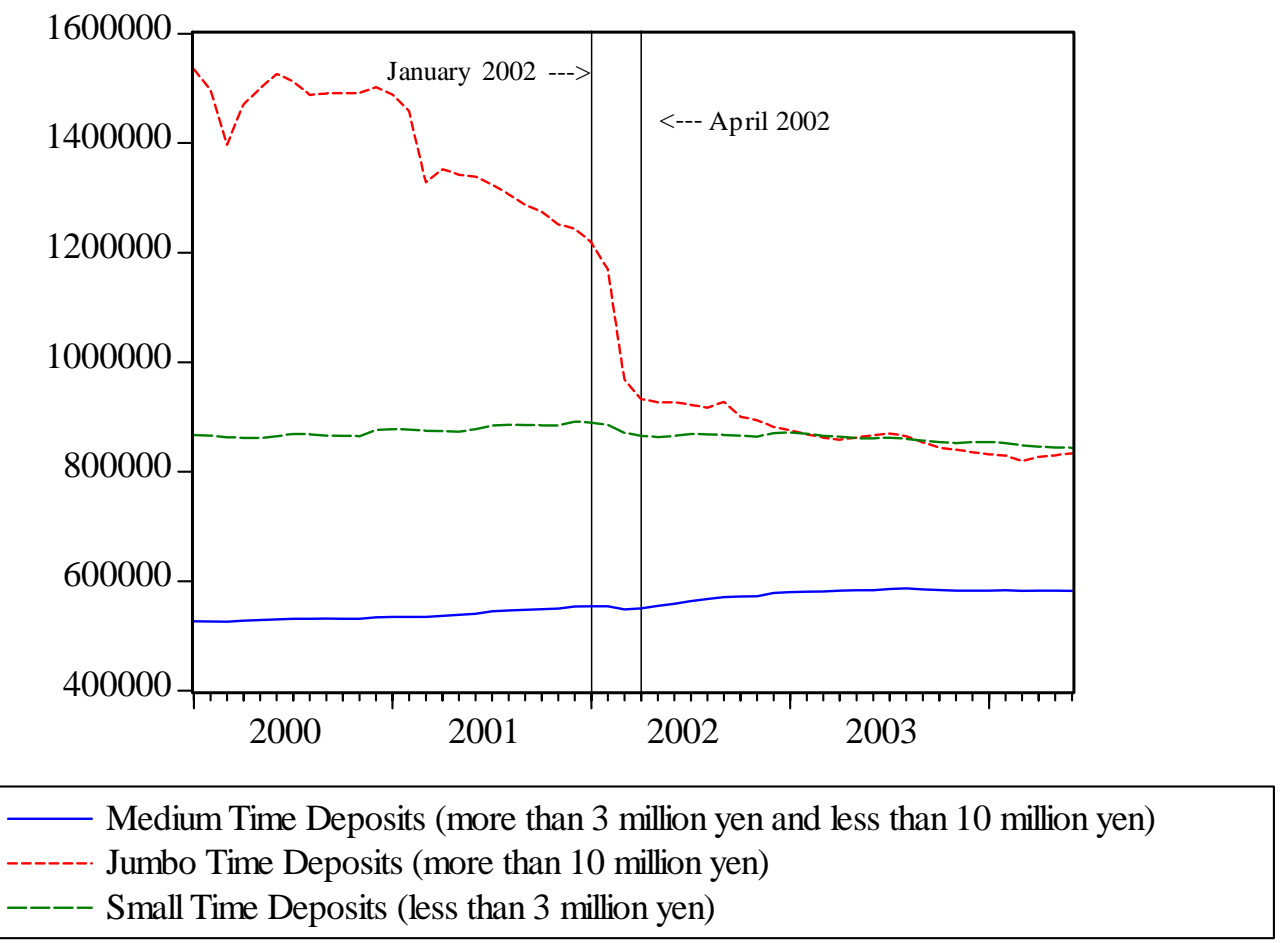

Source: Bank of Japan’s website (http://www.boj.or.jp/stat/dlong_f.htm). 
Figure 4: Difference in Interest Rates between Large Time Deposits and Ordinary Deposits.

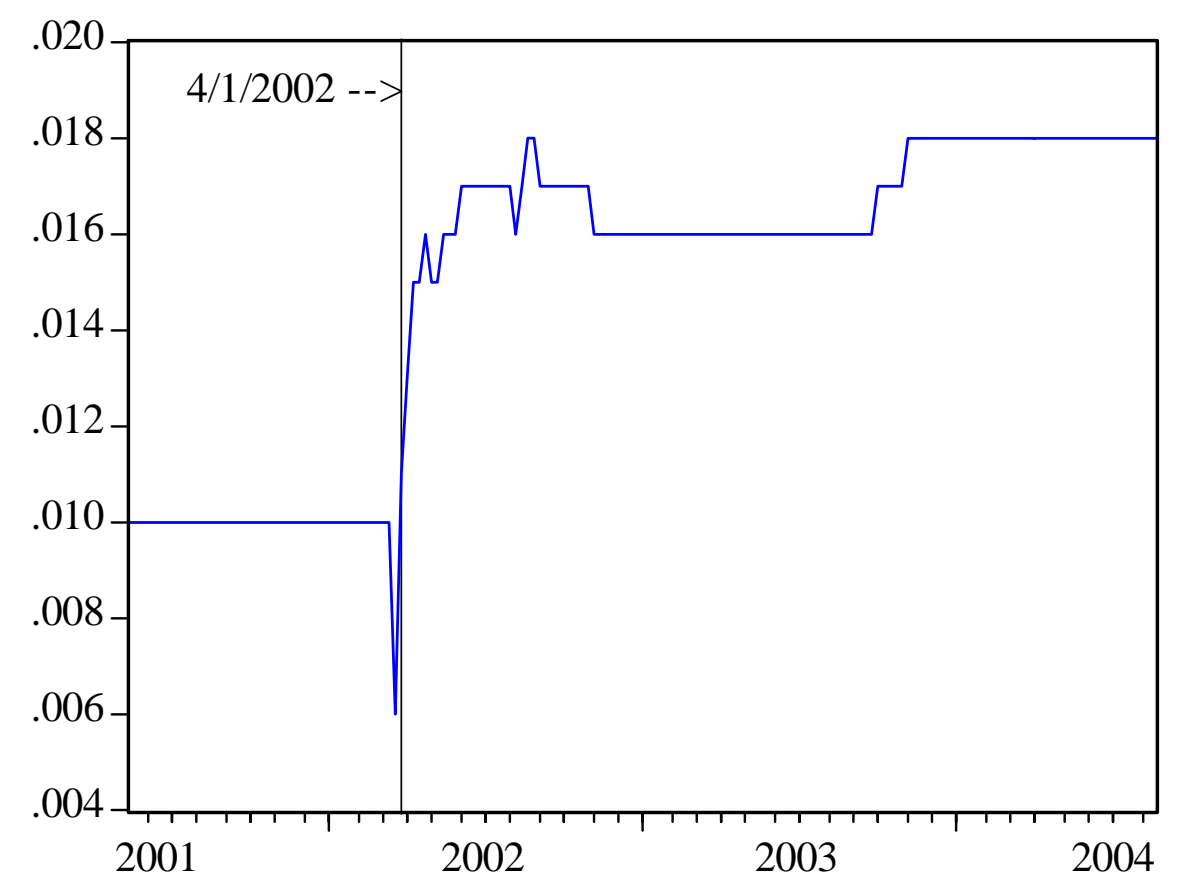

Source: Bank of Japan’s website (http://www.boj.or.jp/stat/dlong_f.htm). 
Figure 5: Standard Deviation of Interest Rates for Time Deposits and Ordinary Deposits

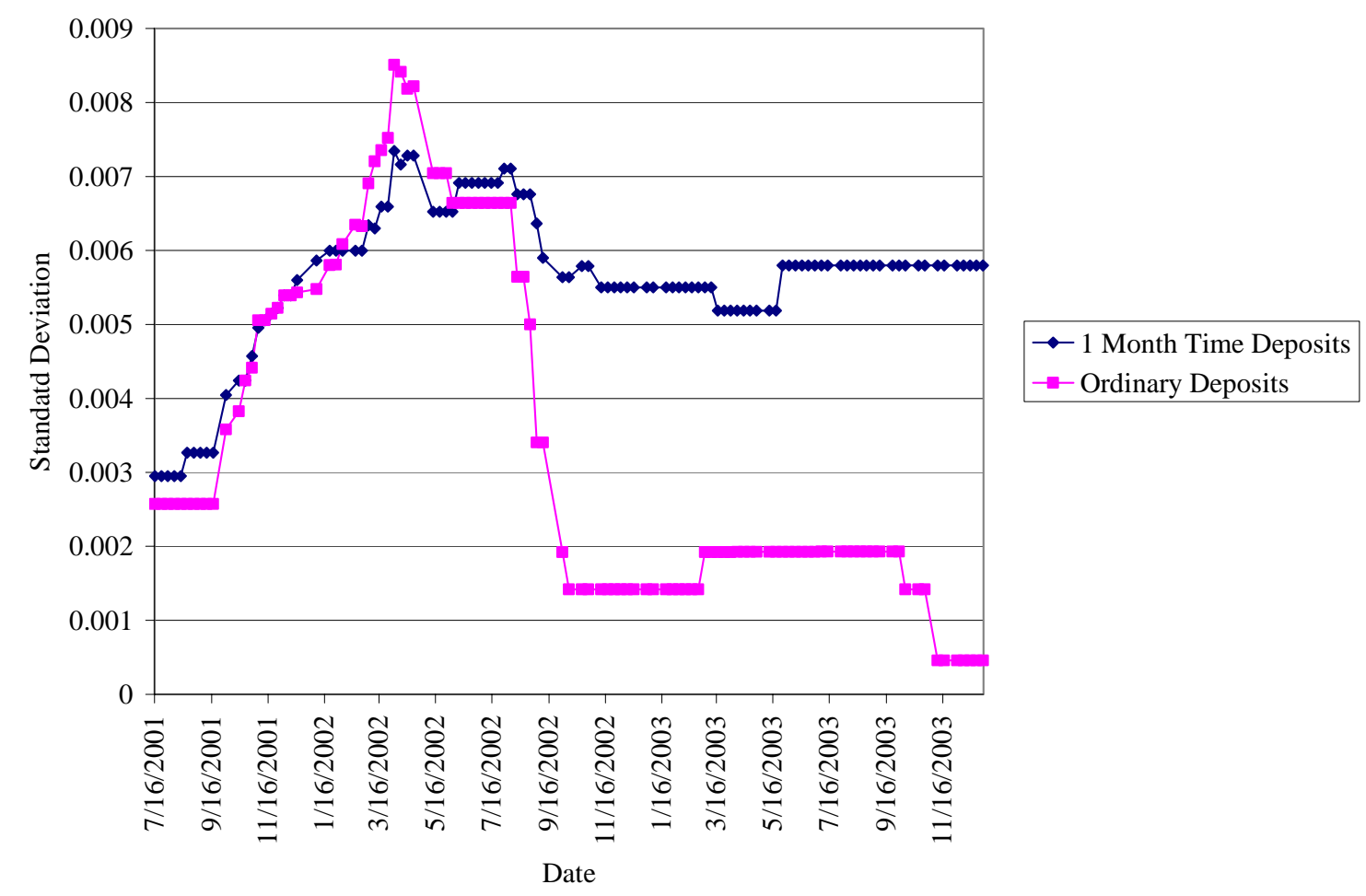

Data Source: Japan Financial News Co 
Figure 6: Standard Deviation of Difference in Interest Rates between Time Deposits and Ordinary Deposits

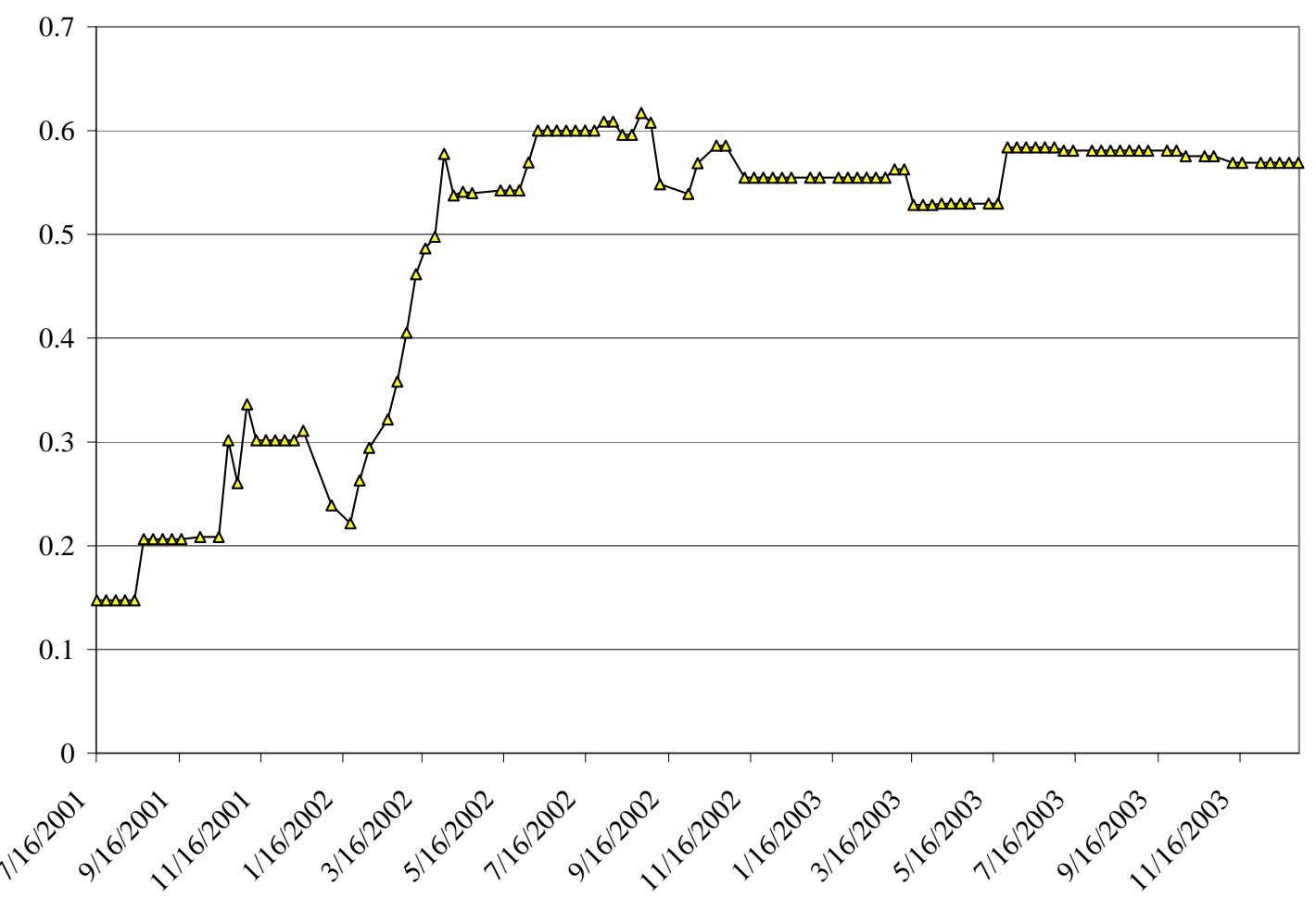

Data Source: Japan Financial News Co 
Figure 7: R-square of Time Deposit Regression Equation and Ordinary Deposits Regression Equation

For each week in 2001-2002, the interest rates of time deposits and ordinary deposits are regressed on dummy variables associated with different levels of Moody's Bank Financial Strength (MBFS) ratings. This figure shows the R-squares of the estimated equations.

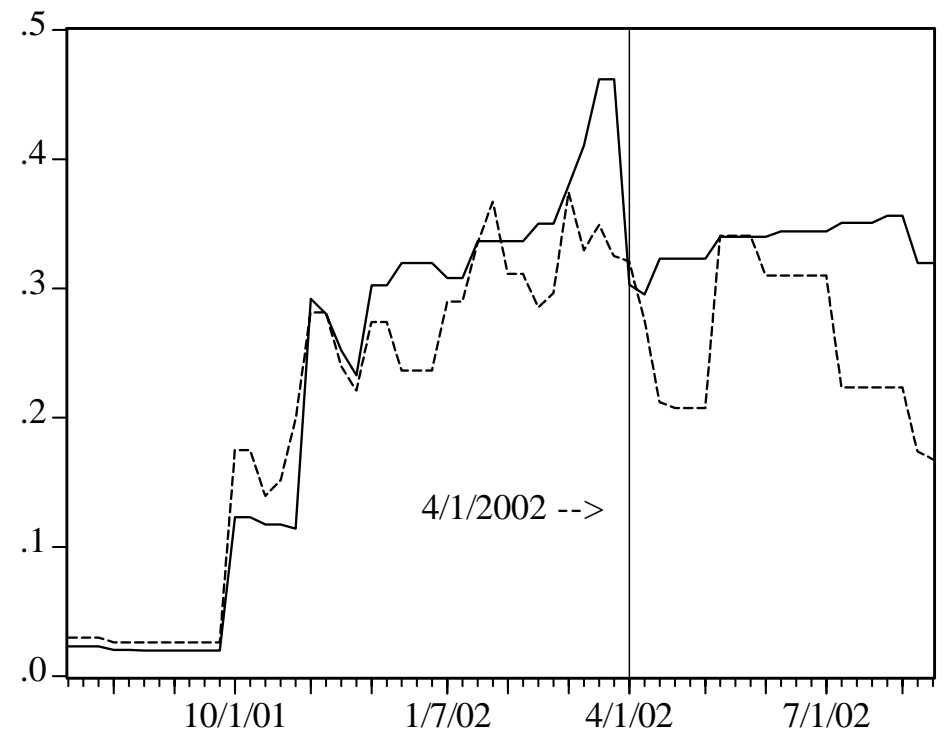

Time Deposits Equation

----- Ordinary Deposits Equation

Figure 8: P-value Associated with the Joint Significance of Moody’s Bank Financial Strength Ratings in the Time Deposit Regression Equation and Ordinary Deposit Regression Equation.

For each week in 2001-2002, the interest rates of time deposits and ordinary deposits are regressed on dummy variables associated with different levels of Moody's Bank Financial Strength (MBFS) ratings. This figure shows the p-values of the null hypothesis that MBFS ratings have no effects on deposit rates.

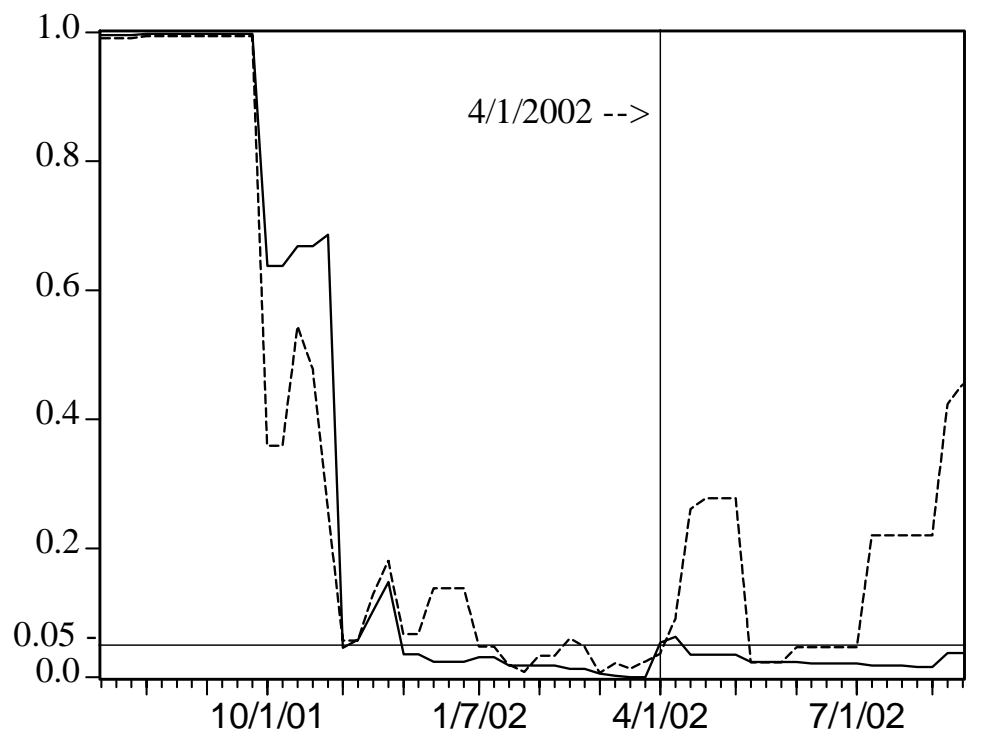

Time Deposits Equation ----- Ordinary Deposits Equation 
Figure 9: Estimated Risk Premium of Deposits

Solid line and dotted lines represent the risk premium in time and ordinary deposits, respectively. Large dots show that the estimated risk premiums are statistically discernible from zero at 5\% significance level.

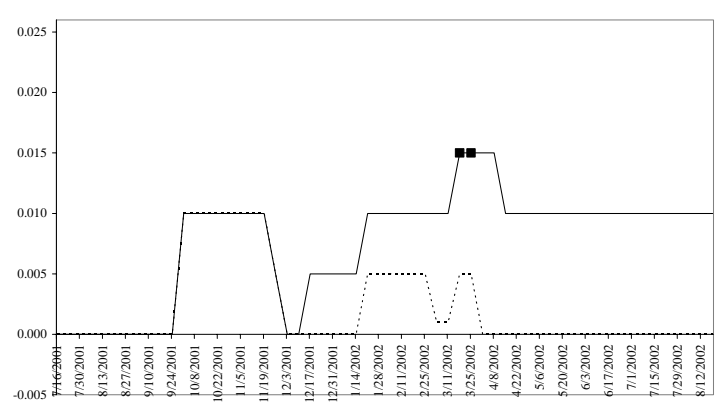

D+
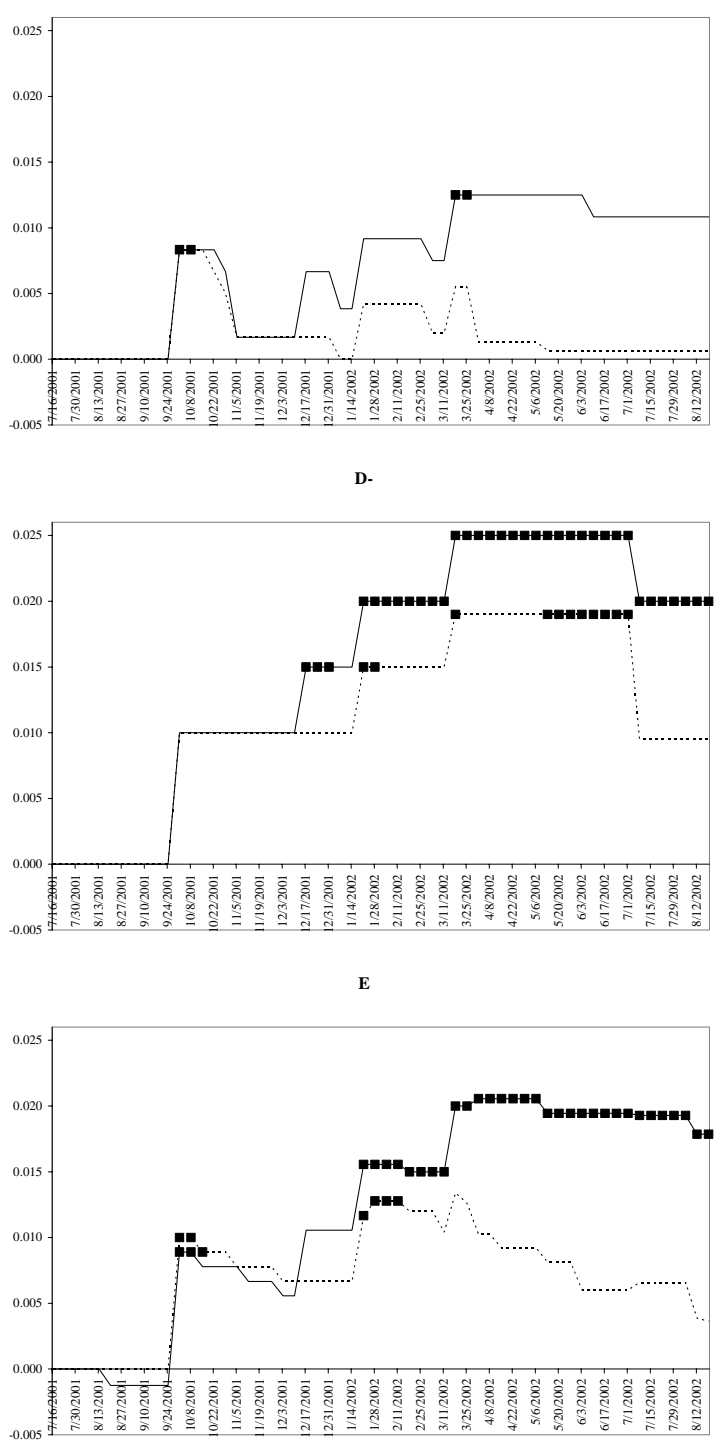

C
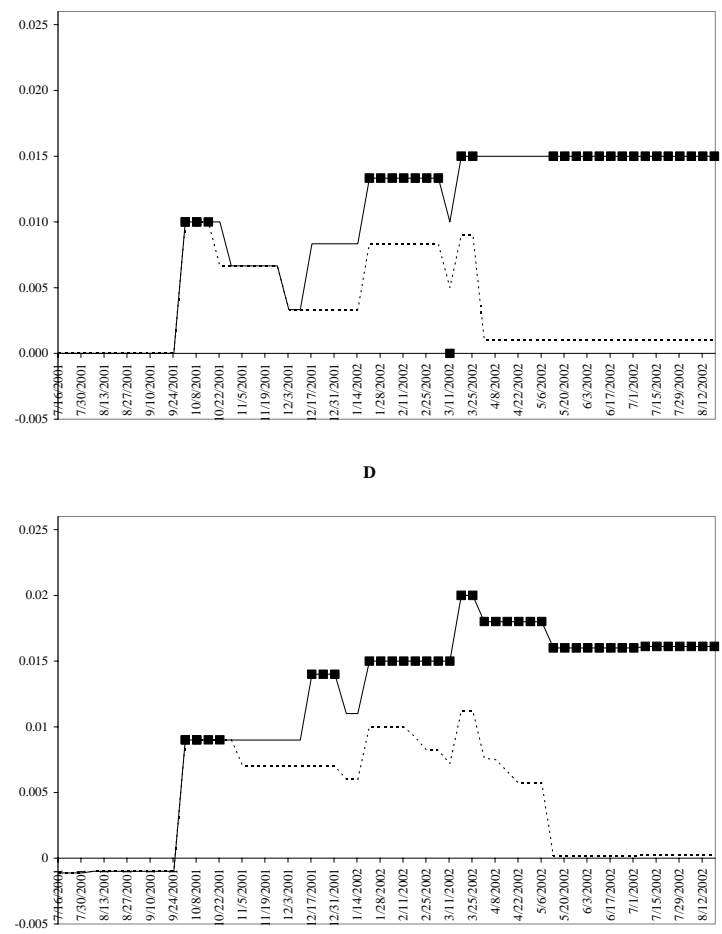

E+

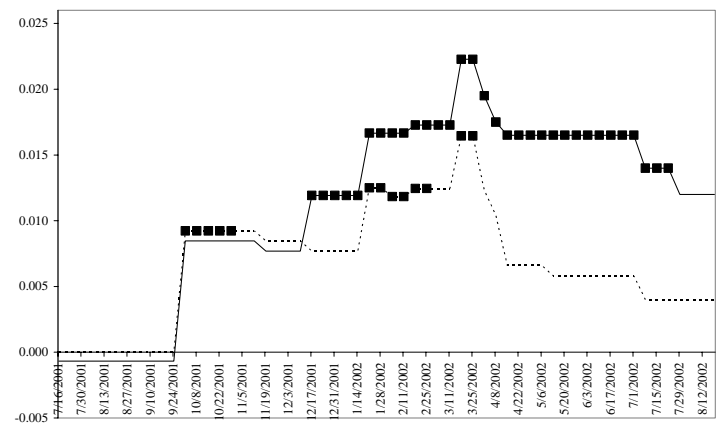

